\title{
27. TIME-TEMPERATURE HISTORIES OF KEROGEN AND MINERAL AMMONIA FROM LEG 139 (MIDDLE VALLEY) SEDIMENTS ${ }^{1}$
}

\author{
Jean K. Whelan, ${ }^{2}$ Jeffrey Seewald, ${ }^{2}$ Lorraine Eglinton, ${ }^{2}$ and Francis P. Miknis ${ }^{3}$
}

\begin{abstract}
Sediments from four Ocean Drilling Program sites in the Middle Valley Hydrothermal area were analyzed for thermal maturity by solid-state ${ }^{13} \mathrm{C}$ nuclear magnetic resonance $\left({ }^{13} \mathrm{C}\right.$ NMR) and thermogravimetric Fourier transform infrared spectroscopy (TG-FTIR). General trends matched those found from vitrinite reflectance $\left(\mathrm{R}_{\mathrm{o}}\right)$ profiles indicating increases in thermal maturity from 200 to $400 \mathrm{~m}$ in Hole $857 \mathrm{C}$ and from 0 to $300 \mathrm{~m}$ in Hole 858A. Holes 858B, 858D, and 858C all showed high maturities in samples shallower than $50 \mathrm{mbsf}$ via both ${ }^{13} \mathrm{C}$ NMR and TG-FTIR. Some samples showed relatively high maturities via these two techniques but relatively low $R_{o}$ values, suggesting that thermal alteration is reflected more rapidly via ${ }^{13} \mathrm{C} N M R$ and TG-FTIR than by vitrinite reflectance in these hydrothermal systems. The TG-FTIR analyses showed strong nitrogen depletion and alteration of the nitrogen-containing material in samples exposed to higher temperatures.

For Hole $857 \mathrm{C}$, maximum temperature exposures estimated from the vitrinite reflectance data using $\mathrm{R}_{\mathrm{o}} /$ maximum temperature calibrations of Barker (1983) and Barker and Pawlewicz (1986) are less than $30^{\circ} \mathrm{C}$ at depths shallower than $47 \mathrm{~m}, 200^{\circ}$ to $225^{\circ} \mathrm{C}$ at $378 \mathrm{~m}$ and $256^{\circ}$ to $>270^{\circ} \mathrm{C}$ at $433 \mathrm{~m}$. These values closely match present-day temperatures of $<30^{\circ} \mathrm{C}, 210^{\circ}$ to $225^{\circ} \mathrm{C}$, and $260^{\circ} \mathrm{C}$, respectively, for the same intervals as measured by downhole temperature and $\delta^{18} \mathrm{O}$. Maximum temperature exposures for other Leg 139 samples for which downhole measurements were not available were estimated to be in the range of $<20^{\circ}$ to $40^{\circ} \mathrm{C}$ for Sample $139-855 \mathrm{C}-1 \mathrm{R}-2,141-144 \mathrm{~cm}$ at $2.91 \mathrm{~m} ;<20^{\circ}$ to $70^{\circ} \mathrm{C}$ for Sample $139-856 \mathrm{~A}-2 \mathrm{H}-4,86-101 \mathrm{~cm}$ at $8.06 \mathrm{~m}$; and $260^{\circ}$ to $>280^{\circ} \mathrm{C}$ for Sample 139-856A-13X-2, 143-149 cm at $108.23 \mathrm{~m}$.

At the bottom of geothermally cold Hole $855 \mathrm{C}$, preferential biodegradation of aliphatic portions of kerogen by aerobic microorganisms, activated by a flow of oxygenated cold seawater from basement, is postulated to be responsible for the absence of aliphatic and the predominance of aromatic carbon atoms detected by ${ }^{13} \mathrm{C}$ NMR. Vitrinite reflectance measurements show this section to be immature.
\end{abstract}

\section{INTRODUCTION}

Many sediments obtained during drilling of the Middle Valley hydrothermal area are very similar to each other (Davis, Mottl, Fisher, et al., 1992) but have been subjected to a wide variety of thermal and hydrothermal regimes. These sediments provided an excellent opportunity to compare various methods of measuring or estimating thermal maturity. This contribution describes measurement of thermal alterations to sediment kerogen as determined by solid-state ${ }^{13} \mathrm{C}$ nuclear magnetic resonance $\left({ }^{13} \mathrm{C}\right.$ NMR $)$ and a new pyrolysis technique, thermogravimetric Fourier transform infrared analysis (TG-FTIR) (Whelan et al., 1988 and 1990) compared with vitrinite reflectance $\left(R_{o}\right)$ profiles (Mao et al., this volume). Initial results of the TG-FTIR technique are described with respect to alterations to mineral nitrogen from the hydrothermal system. The NMR, TG-FTIR, and $\% \mathrm{R}_{\mathrm{o}}$ data are all compared to direct temperature measurements (Davis and Wang, this volume; Davis, Mottl, Fisher, et al., 1992). In addition, estimates of maximum temperature exposure are carried out by using calibrations of $\% \mathrm{R}_{\mathrm{o}}$ vs. maximum temperature from various laboratories.

\section{METHODS}

Elemental analyses on whole-rock samples were carried out aboard ship using a Carlo Erba CHNS analyzer (Davis, Mottl, Fisher, et al., 1992, p. 76). Precise measurements were obtained on these low total organic carbon (TOC) rocks (Davis, Mottl, Fisher, et al., 1992, p. 76). Additional shore-based analyses were carried out using a Perkin-Elmer $\mathrm{CHN}$ analyzer and the method of Krom and Berner

\footnotetext{
'Mottl, M.J., Davis, E.E., Fisher, A.T., and Slack, J.F. (Eds.), 1994. Proc. ODP. Sci. Results, 139: College Station, TX (Ocean Drilling Program).

${ }^{2}$ Department of Marine Chemistry and Geochemistry, Woods Hole Oceanographic Institution, Woods Hole, MA 02543, U.S.A.

${ }^{3}$ Western Research Institute, the University of Wyoming Research Corporation, P.O. Box 3395, Laramie, WY 82071-3395, U.S.A.
}

(1983). Because TOC values were relatively constant within a particular core, values from an adjacent section (generally within $3 \mathrm{~m}$ ) were used in a few cases where insufficient sample was available to make the measurement on the sample used for other measurements, as indicated in Table 1.

TG-FTIR measurements were carried out on whole rocks as described in Whelan et al., 1988 and 1990.

Kerogen isolation was carried out by treatment of powdered whole rock, first with $6 \mathrm{~N} \mathrm{HCl}$ and then with $\mathrm{HF}$ as described in Durand and Nicaise (1980).

Vitrinite reflectance and thermal alteration (TAI) measurements were carried out as described in Mao et al., this volume.

Solid-state NMR measurements were made using a Chemagnetics CMX 100/200 solids NMR spectrometer. These measurements were carried out on isolated kerogens in most cases.

An attempt was also made to carry out measurements on whole rocks with a large-diameter probe. However, because of the organiclean nature of the rocks, no signal was obtained above background.

For the kerogen measurements, carbon aromaticity measurements were made at a ${ }^{13} \mathrm{C}$ frequency of $25 \mathrm{MHz}$ using the technique of cross polarization $(\mathrm{CP})$ with magic-angle spinning (MAS) and high-power decoupling. A 9.5-mm diameter zirconia bullet spinner was used. Spinning rates were between 3.5 and $4 \mathrm{kHz}$. Other instrumental parameters were a $90 \mathrm{R}$ pulse width of $5.1 \mathrm{~ms}$, a contact time of $1 \mathrm{~ms}$, and a pulse delay of $1 \mathrm{~s}$. A $50 \mathrm{~Hz}$ exponential multiplier was applied to the free induction decay of each ${ }^{13} \mathrm{C}$ spectrum before integration. These parameters are typical for CP/MAS measurements on these types of materials (Miknis et al., 1982; Wilson et al., 1991). The number of transients varied between 43,200 and 64,800 counts because of the low levels of total organic carbon (TOC) in many of the kerogen concentrates.

Concerns about the accuracy of the carbon aromaticity measurements have been discussed (Snape et al., 1989), including the use of a single contact time for determining carbon aromaticities. Aliphatic and aromatic carbons are known to cross polarize at different rates; therefore a single contact time may not give representative aromatici- 
Table 1. Summary of TG-FTIR, NMR, TOC, and $\% R_{0}$ data for Leg 139.

\begin{tabular}{|c|c|c|c|c|c|c|c|c|c|c|c|}
\hline \multirow[b]{2}{*}{$\begin{array}{l}\text { Core, section, } \\
\text { interval }(\mathrm{cm})\end{array}$} & \multirow[b]{2}{*}{$\begin{array}{l}\text { Depth } \\
\text { (mbsf) }\end{array}$} & \multirow[b]{2}{*}{$\begin{array}{c}\text { NMR } \\
f^{\prime} a\end{array}$} & \multirow{2}{*}{$\begin{array}{c}R_{0} \text { Equiv } \\
\% \\
\text { (TAI) }\end{array}$} & \multirow{2}{*}{$\begin{array}{c}\mathrm{R}_{\mathrm{o}} \\
\% \\
\text { (vit refle) }\end{array}$} & \multicolumn{7}{|c|}{ TG-FTIR } \\
\hline & & & & & $\begin{array}{c}\mathrm{T}_{\max } \mathrm{NH}_{3}(1) \\
{ }^{\circ} \mathrm{C}, \min \end{array}$ & $\begin{array}{c}\mathrm{T}_{\max } \mathrm{NH}_{3}(2) \\
{ }^{\circ} \mathrm{C}, \max \end{array}$ & $\begin{array}{l}\text { Wt\% NH } \\
3(\mathrm{TG}+)\end{array}$ & $\begin{array}{l}\mathrm{Wt}_{\mathrm{t}} \% \mathrm{NH}_{3} \\
\text { (EA) }\end{array}$ & $\underset{(\min )}{\mathrm{TmaxCH} 4}$ & $\begin{array}{c}\mathrm{T}_{\max } \mathrm{CH} 4 \\
(\max )\end{array}$ & $\begin{array}{l}\text { TOC } \\
(\%)\end{array}$ \\
\hline \multicolumn{12}{|l|}{$139-855 \mathrm{~A}-$} \\
\hline $\begin{array}{l}\text { IR-2, } 141-144 \\
3 R-2,137-140\end{array}$ & $\begin{array}{r}2.91 \\
19.47\end{array}$ & 0.56 & $\begin{array}{l}0.3 \\
0.3\end{array}$ & $0.42 \pm 0.04$ & 594 & 647 & 0.069 & $\begin{array}{l}0.06^{\mathrm{a}} \\
0.06\end{array}$ & 765 & 765 & $\begin{array}{l}0.5 \mathrm{a} \\
0.5^{\mathrm{a}}\end{array}$ \\
\hline \multicolumn{12}{|l|}{$139-855 \mathrm{C}-$} \\
\hline $11 \mathrm{R}-2,10-13$ & 96.20 & NM & 0.38 & $0.43 \pm 0.03$ & & & & $0.026^{\mathrm{a}}$ & & & $0.11^{a}$ \\
\hline \multicolumn{12}{|l|}{ 139-856A- } \\
\hline $2 \mathrm{H}-5,137-140$ & 10.07 & 0.44 & 0.4 & 0.57 & ND & ND & ND & $0.160^{\mathrm{a}}$ & NOD & NDD & $0.49^{\mathrm{a}}$ \\
\hline $13 X-2,143-149$ & 108.23 & 0.9 & $>2.58$ & $2.11 \pm 0.29$ & ND & ND & ND & $0.092^{\mathrm{a}}$ & ND & ND & 0.15 \\
\hline \multicolumn{12}{|l|}{$139-856 \mathrm{~B}-$} \\
\hline \multirow{2}{*}{\multicolumn{10}{|c|}{ 139-857A- }} & $\mathrm{ND}$ & $0.32^{3}$ \\
\hline $1 \mathrm{H}-2,95-109$ & 4.35 & 0.53 & & & & & & & & & \\
\hline $4 \mathrm{H}-4,137-140$ & 27.77 & 0.51 & 0.2 & $0.38 \pm 0.04$ & ND & ND & ND & ND & ND & ND & $0.49^{\mathrm{a}}$ \\
\hline $6 \mathrm{H}-4,137-140$ & 46.77 & 0.64 & 0.38 & $0.37 \pm 0.09$ & ND & ND & ND & ND & ND & ND & $0.37^{\mathrm{a}}$ \\
\hline $9 \mathrm{H}-1,110-116$ & 70.50 & 0.63 & 0.45 & $0.41 \pm 0.04^{b}$ & ND & $\mathrm{ND}$ & $\mathrm{ND}$ & ND & ND & ND & 0.45 \\
\hline \multicolumn{12}{|l|}{$\begin{array}{l}139-857 \mathrm{C}- \\
6 \mathrm{R}-62-64\end{array}$} \\
\hline & 88.32 & 0.56 & 0.38 & $0.62 \pm 0.10$ & ND & ND & ND & $0.069^{\mathrm{a}}$ & ND & ND & 0.4 \\
\hline $\begin{array}{l}13 R-2,105-109 \\
14 R-2,37-43\end{array}$ & $\begin{array}{l}155.65 \\
164.67\end{array}$ & 0.65 & 0.61 & ND & 575 & 575 & 0.065 & $\begin{array}{l}0.069 \\
0.049^{\mathrm{a}}\end{array}$ & 538 & 775 & 0.44 \\
\hline $16 \mathrm{R}-1,0-2$ & 182.20 & 0.65 & $0.61^{b}$ & ND & ND & ND & ND & $\begin{array}{l}0.049^{\prime \prime} \\
0.017\end{array}$ & ND & ND & 0.17 \\
\hline $17 \mathrm{R}-2,126-130$ & 194.66 & & $0.6 \mathrm{I}_{\mathrm{b}}$ & $0.67 \pm 0.14$ & 579 & 661 & 0.028 & ND & 530 & 803 & ND \\
\hline $19 \mathrm{R}-1,74-78$ & 212.04 & 0.67 & $0.78 \mathrm{~b}$ & $0.7 \pm 0.12^{b}$ & 626 & 626 & 0.037 & $0.023^{\mathrm{a}}$ & 512 & $749-792$ & $0.22^{\mathrm{a}}$ \\
\hline $23 \mathrm{R}-1,5-8$ & 249.95 & NM & $0.69^{\mathrm{b}}$ & $0.75 \pm 0.10^{b}$ & 630 & 630 & 0.041 & 0.045 & 527 & 780 & ND \\
\hline $25 \mathrm{R}-1,89-93$ & 269.69 & & 0.38 & $0.95 \pm 0.08$ & 602 & 602 & 0.074 & 0.051 & 591 & 788 & 0.48 \\
\hline $28 \mathrm{R}-2,27-30$ & 295.57 & & 0.98 & $1.10 \pm 0.16$ & 615 & 615 & 0.054 & 0.042 & 581 & 791 & 0.36 \\
\hline $3 \mid \mathbb{R}-1,111-115$ & 323.81 & & 1.1 to $1.2^{b}$ & $1.2 \pm 0.15^{\mathrm{b}}$ & 611 & 611 & 0.075 & 0.041 & 622 & 791 & 0.39 \\
\hline $35 \mathrm{R}-3,67-71$ & 344.97 & NM & & & & & $0.046^{\mathrm{a}}$ & & & & $0.37^{\mathrm{a}}$ \\
\hline $41 \mathrm{R}-3,66-71$ & 378.56 & 0.91 & ND & $1.7 \pm 0.12^{b}$ & 631 & 631 & 0.06 & 0.069 & 522 & 829 & 0.28 \\
\hline $53 R-1,27-30$ & 433.07 & & $>2.58$ & $>2.48 \pm .019^{\mathrm{b}}$ & 652 & 652 & 0.025 & 0.02 & 536 & 812 & 0.27 \\
\hline \multicolumn{12}{|l|}{ 139-857D- } \\
\hline 2IR-1, 146-148 & 773.66 & & ND & ND & ND & ND & 0 & 0.001 & $562-900$ & $562-900$ & 0.13 \\
\hline \multicolumn{12}{|l|}{ 139-858A- } \\
\hline $1 \mathrm{H}-1,93-95$ & $\begin{array}{l}0.93 \\
2.82\end{array}$ & & & $0.43 \pm .09$ & & & & 0.053 & & & 0.69 \\
\hline $2 \mathrm{H}-1,42-44$ & & & 0.3 & & & & & 0.032 & & & 0.3 \\
\hline $2 \mathrm{H}-3,141-145$ & 6.81 & 0.46 & & & & & & ND & & & ND \\
\hline $2 \mathrm{H}-5,6-10$ & 8.46 & & 0.38 & & & & & ND & & & ND \\
\hline $3 \mathrm{H}-4,68-72$ & 17.08 & & 0.00 & $0.52 \pm 0.04$ & & & & $0.032^{\mathrm{a}}$ & & & $0.27^{\mathrm{a}}$ \\
\hline $6 \mathrm{H}-3,105-107$ & 44.45 & & & $1.24 \pm .10$ & & & & $0.036^{\mathrm{a}}$ & & & $0.32^{\mathrm{a}}$ \\
\hline $7 \mathrm{H}-3,27-30$ & 53.17 & NM & & & & & & ND & & & ND \\
\hline $7 \mathrm{H}-3,72-75$ & 53.62 & & 0.98 & & & & & $0.039^{\mathrm{a}}$ & & & $0.16^{\mathrm{a}}$ \\
\hline $19 \mathrm{X}-1,9-11$ & 149.39 & 0.95 & & & & & & 0.037 & & & 0.21 \\
\hline $19 \mathrm{X}-1,32-34$ & 149.62 & & 1.16 & $1.67 \pm .16$ & & & & $\mathrm{ND} *$ & & & ND \\
\hline $21 X-1,110-113$ & 169.70 & 0.95 & & & & & & $0.014^{*}$ & & & $0.17^{\mathrm{a}}$ \\
\hline $24 \mathrm{X}-1,54-56$ & 198.14 & & 2.58 & $2.61 \pm .20$ & & & & $0.036^{\mathrm{a}}$ & & & $0.32^{\mathrm{a}}$ \\
\hline $32 X-1,14-15$ & 274.64 & 0.97 & $>2.58$ & $2.61 \pm 0.20^{\mathrm{b}}$ & 714 & 714 & 0.0071 & 0.015 & 549 & 809 & $0.2^{\mathrm{a}}$ \\
\hline \multicolumn{12}{|l|}{ 139-858B- } \\
\hline 1H-3, 101-104 & $\begin{array}{l}4.01 \\
507\end{array}$ & & 0.3 & $0.45 \pm .03$ & 591 & 656 & 0.0036 & $0.04^{\mathrm{a}}$ & $762-855$ & $762-855$ & $0.51^{\mathrm{a}}$ \\
\hline 1H- $4,147-150$ & & 0.71 & 0.45 & & ND & ND & ND & $0.051^{\mathrm{a}}$ & ND & ND & $0.49^{\mathrm{n}}$ \\
\hline IH-CC & 7.20 & & & $0.52 \pm 0.08$ & ND & ND & ND & $0.033^{\mathrm{a}}$ & ND & ND & 0.26 \\
\hline $5 \mathrm{H}-3,137-140$ & 28.27 & NM & $>2.58^{\mathrm{b}}$ & ND & ND & ND & 0.0029 & 0 & $506 ; 572$ & 798 & 0.09 \\
\hline 139-858C- & & & & & & & & & & & \\
\hline 1H-1, 2-17 & 0.02 & NM & $0.3^{\mathrm{b}}$ & $0.45 \pm 0.06^{\mathrm{b}}$ & $\begin{array}{l}423 \\
500\end{array}$ & 623 & 0.18 & 0.1 & $327-542$ & $\begin{array}{l}743 \\
800\end{array}$ & 1.02 \\
\hline $\begin{array}{l}2 \mathrm{H}-1,1-15 \\
5 \mathrm{H}-1,150-52\end{array}$ & $\begin{array}{r}3.51 \\
25.00\end{array}$ & $\begin{array}{l}\text { NM } \\
\text { NM }\end{array}$ & $\begin{array}{l}0.38^{\circ} \\
\mathrm{ND}\end{array}$ & $\begin{array}{c}0.49 \pm 0.07^{\mathrm{b}} \\
\mathrm{ND}\end{array}$ & $\begin{array}{l}590 \\
511\end{array}$ & $\begin{array}{l}647 \\
645\end{array}$ & $\begin{array}{l}0.044 \\
0.0024\end{array}$ & $\begin{array}{l}0.04^{\mathrm{a}} \\
0.004\end{array}$ & $\begin{array}{l}332-528 \\
369-605\end{array}$ & $\begin{array}{c}809 \\
739-881\end{array}$ & $\begin{array}{l}0.5 \mathrm{a} \\
0.1^{\mathrm{a}}\end{array}$ \\
\hline $7 \mathrm{H}-2,5-7$ & 43.05 & 0.97 & $>2.58^{\mathrm{b}}$ & $1.54 \pm 0.16$ & ND & ND & 0 & $0.013^{\mathrm{a}}$ & $447-607$ & $742 ; 834$ & $0.22^{\mathrm{a}}$ \\
\hline 139-858D- & & & & & & & & & & & \\
\hline $1 \mathrm{H}-1,0-30$ & 0.00 & NM & & & & & & $0.072^{\mathrm{a}}$ & & & $0.86^{a}$ \\
\hline $2 \mathrm{H}-3,137-141$ & 13.67 & NM & & & & & & $0.033^{\mathrm{a}}$ & & & $0.34^{3}$ \\
\hline $4 \mathrm{H}-3,137-140$ & 23.12 & 0.84 & & & & & & $0.03^{\mathrm{a}}$ & & & $0.25 \mathrm{a}$ \\
\hline
\end{tabular}

Notes: $\mathrm{ND}=$ no data and $\mathrm{NM}=$ not able to measure.

${ }^{\text {a }}$ Estimated from adjacent samples (Davis, Mottl. Fisher, et al., 1992)

${ }^{b}$ Extrapolated from surrounding samples (Mao et al., this volume)

ties. However, Wilson et al. (1991) compared aromaticities for coaly source rocks from the Brent group (North Sea). The contact times were varied between $10 \mathrm{~ms}$ and $8 \mathrm{~ms}$ and signal intensities were calculated by curve fitting. In all but one case, the aromaticities agreed within experimental error. They concluded that CP/MAS ${ }^{13} \mathrm{C}$ NMR aromaticity made at a $1 \mathrm{~ms}$ contact time could be used with confidence. Thus, a 1-ms contact time was utilized in this work.

All spectra were manually phased and integrated using the instrument's dedicated computer software. Because of the low levels of carbon in the kerogens and the large number of transients required to obtain a spectrum, some broad signals from the NMR probe were also recorded. Consequently, a probe background spectrum was subtracted from each kerogen spectrum prior to integration.

The carbon aromaticity measurements were integrated over the range from $360 \mathrm{ppm}$ to $-160 \mathrm{ppm}$. This large range was required to include any contributions from spinning side bands in the aromaticity measurements. The region between $340 \mathrm{ppm}$ and $90 \mathrm{ppm}$ was considered the aromatic region, and included unresolved contributions from 


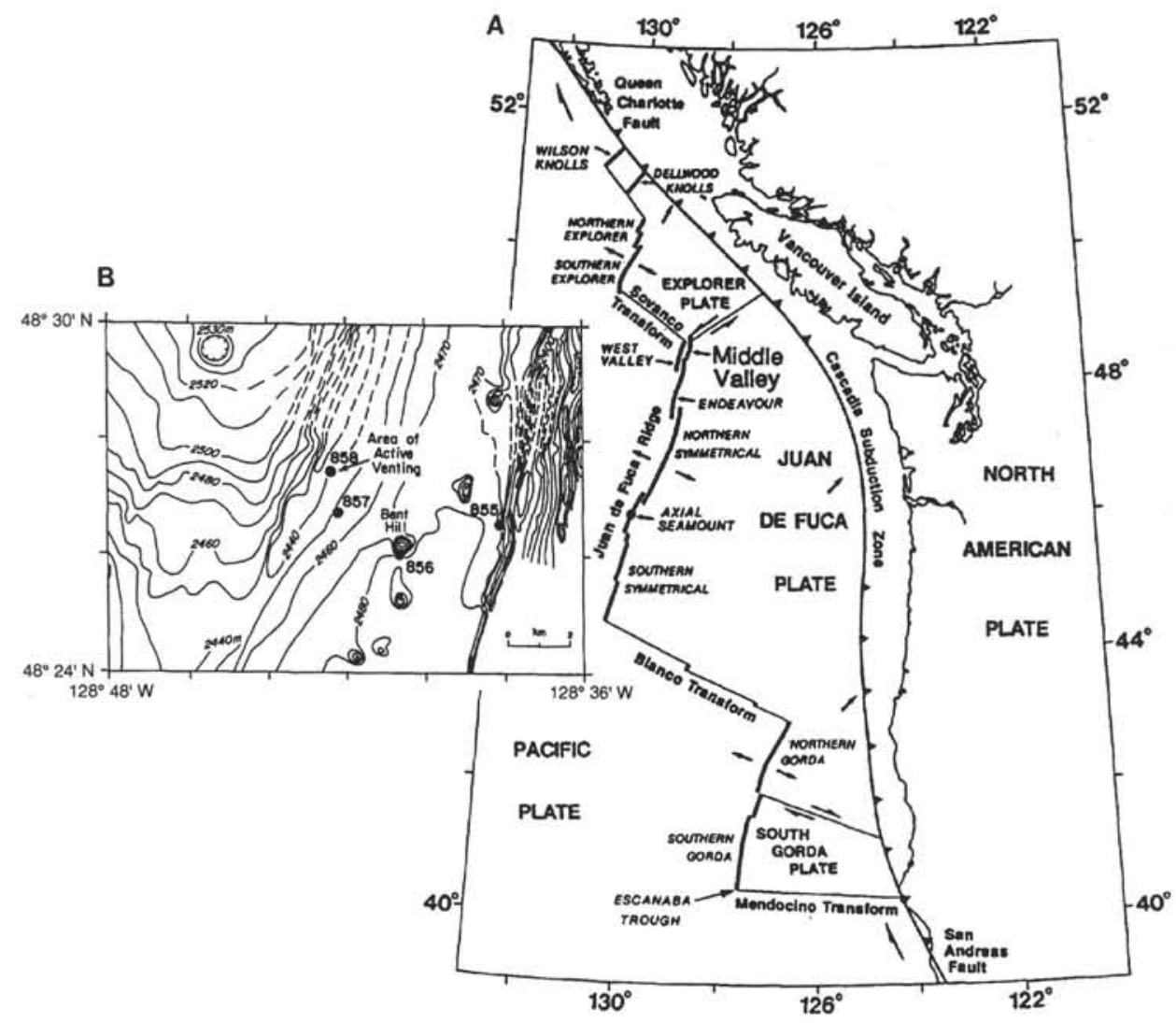

Figure 1. A. Location of Middle Valley hydrothermal area studied during Leg 139. B. Locations of holes drilled during Leg 139 in Middle Valley. At the time of drilling, active venting was occurring at Site 858 .

any carbonyl carbons in the region $165 \mathrm{ppm}$ to $210 \mathrm{ppm}$ which might be present. The region between 90 and -20 ppm was considered the aliphatic carbon region. The integrated intensity between $-20 \mathrm{ppm}$ and $-80 \mathrm{ppm}$ was added to the aromatic carbon integral.

\section{DESCRIPTION OF SAMPLES}

The location of the sites from which samples were recovered for this work are shown in Figure 1. TOC was low (Table 1), ranging from a maximum of about $0.5 \%$ to values of less than $0.1 \%$ in deeper and more hydrothermally altered sediments (Davis, Mottl, Fisher, et al., 1992).

\section{Site 855}

Site 855 was drilled to determine the nature of seawater recharge outside the area of hydrothermal upflow. Pore-water geochemical data confirm that cold, recharging seawater permeates the basement at this site. The chemical changes observed in the fluid, sediment, and basalt are associated with low-temperature biogenic reactions and seafloor weathering (Davis, Mottl, Fisher, et al., 1992).

\section{Site 856}

Site 856 was drilled into a fossil hydrothermal upflow zone. Hole $856 \mathrm{~A}$ was drilled at the center of a 400 -m diameter hill of sediment which has been uplifted $50 \mathrm{~m}$ above the surrounding turbidite-filled valley floor during the Holocene. Indications of former hydrothermal activity include growth of authigenic carbonate nodules; precipitation and subsequent dissolution of anhydrite; alteration of mafic minerals and plagioclase feldspar; formation of pyrite, albite, and chlorite; and the presence of a massive sulfide deposit at the site.

\section{Site 857}

Site 857 was located $1.6 \mathrm{~km}$ south of the zone of active venting (Fig. 1). Four holes were drilled into this high-temperature hydrothermal reservoir (heat flow $0.8 \mathrm{~W} / \mathrm{m}^{2}$ ) outside the area of active hydrothermal flow. The deepest hole penetrated $471 \mathrm{~m}$ of sediment and metasedimentary rock and $467 \mathrm{~m}$ of diabasic sills interlayered with metasedimentary rock. The thermal structure of the upper part of the sediment is conductive to about the depth of the sheeted sill complex beginning at $470 \mathrm{~m}$. A zone between $200 \mathrm{~m}$ and $400 \mathrm{~m}$ depth shows sodium depletion in pore water and strong sodium metasomatism in the sediments which, together with strong concentration gradients in the composition of pore fluid, require lateral flow of hydrothermal fluid in this zone. Mass balance constraints further suggest that many volumes of pore water have flushed through this zone. The sill-sediment complex below $470 \mathrm{~m}$ appears to be isothermal at approximately $275^{\circ} \mathrm{C}$ (as determined by direct temperature measurements; Davis and Wang, this volume), the temperature of the active hydrothermal vent area at Site $858,1.6 \mathrm{~km}$ to the north.

\section{Site 858}

Site 858 drilling defined the temperature structure in and around the hydrothermal upflow zone of the Dead Dog vent field (Fig. 1). The thermal anomaly associated with the active vents is highly localized and appears to be nearly isothermal at the temperature of the vents $\left(275^{\circ} \mathrm{C}\right)$ from a shallow depth down to basement. Thermal induration and hydrothermal alteration of the sediment are similar to that found at Site 857 , but occur at shallower depth in accordance with the higher temperature. Near-surface gradients in pore-fluid and hydrocarbon composition are interpreted to be maintained by lateral flow of hydrother- 


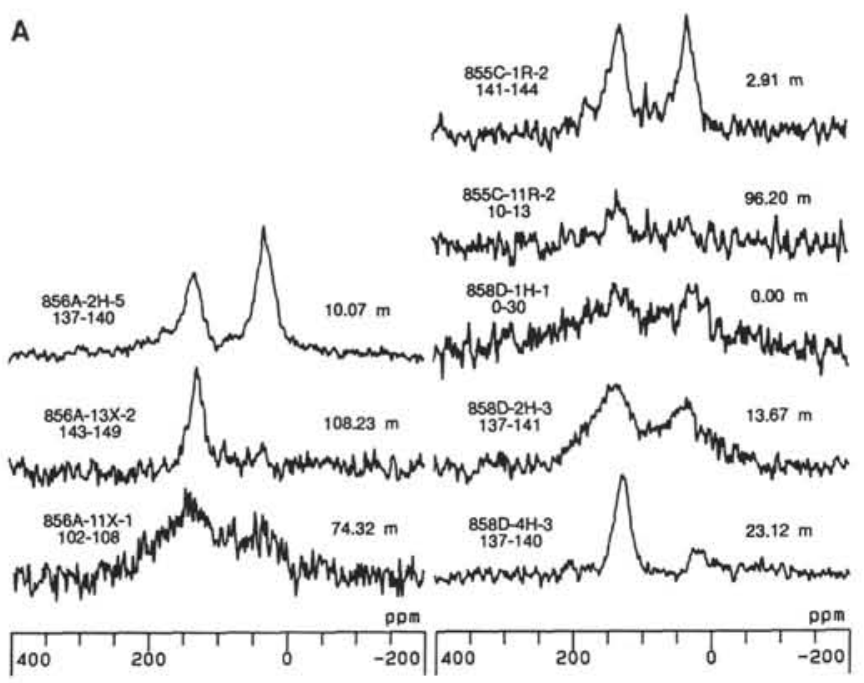

Figure 2. Solid state ${ }^{13} \mathrm{C}$ nuclear magnetic resonance spectra of Leg 139 kerogens with sub-bottom depths indicated. A. Holes 855C, 856A, and 858D. B. Holes $857 \mathrm{~A}$ and $857 \mathrm{C}$. C. Holes $858 \mathrm{~A}, 858 \mathrm{~B}$, and $858 \mathrm{C}$.

mal fluid. Acarbonate- and silica-cemented zone at about 20 to $30 \mathrm{mbsf}$ was encountered and interpreted to be associated with near-surface lateral flow of hydrothermal fluid (Davis, Mottl, Fisher, et al., 1992).

Hole $858 \mathrm{~B}$ was drilled at the base of one of the hydrothermal mounds within $20 \mathrm{~m}$ of an active $265^{\circ} \mathrm{C}$ vent. Magnesium-rich smectite, anhydrite, and pyrite occur at shallow depth in this hole. The larger-scale control on the location of the hydrothermal upflow zone was established by deeper drilling at Holes $858 \mathrm{~A}, 858 \mathrm{~F}$, and $858 \mathrm{G}$. Hole $858 \mathrm{~A}$, on the flank of the venting area, was drilled to a depth of $333 \mathrm{~m}$ and did not encounter basaltic rock. Hole $858 \mathrm{~F}$, in the core of the vent area, encountered basalt pillows and massive flows from $258 \mathrm{~m}$ to the bottom of the hole at $433 \mathrm{~m}$. These flows occur more than $200 \mathrm{~m}$ higher in the sedimentary section than sills drilled at Site 857 . Seismic reflection profiles show that this volcanic high is very narrow, consistent with the absence of igneous rock in Hole 858A, less than $200 \mathrm{~m}$ west.

\section{RESULTS}

\section{Nuclear Magnetic Resonance Data}

Nuclear magnetic resonance data are presented in Figures $2-4$ and in Tables 1-3. The upfield signal above $90 \mathrm{ppm}$ is considered to be the aliphatic carbon region and the downfield region below $90 \mathrm{ppm}$ the aromatic carbon region (see "Methods" section, this chapter). With increasing temperature and maturity, the aliphatic signal disappears while the aromatic signal remains the same or increases. This relationship is expressed quantitatively by $\mathrm{f}^{\prime} \mathrm{a}$, termed the aromaticity, which is the ratio of aromatic to aliphatic plus aromatic carbon atoms. As geothermal temperature or maturity of the kerogen increases, $f^{\prime} a$ approaches its theoretical maximum value of 1 . In Figure 2, this change is observed as the progressive disappearance of the upfield aliphatic signal and the relative enhancement of the lower field aromatic signal. For example, a strong aliphatic signal is observed in Sample 139-855C-1R-2, 141-144 cm (2.91 m), which has not been heated $\left(\mathrm{f}^{\prime} \mathrm{a}=0.56\right)$, while only a weak aromatic and no aliphatic signal is observed for Sample 855C-11R-2, 10-13 cm (96.20 m). Due to the weakness of the kerogen signal relative to background, it was not possible to calculate $\mathrm{f}^{\prime} \mathrm{a}$ for the latter sample. A similar change is observable between Samples 857A-1H-2, 95-109 cm (4.35 m) and 857C$41 \mathrm{R}-3,66-71 \mathrm{~cm}(378.6 \mathrm{~m})$, where the downhole temperature also increases by about $200^{\circ} \mathrm{C}$ in the deeper sample (Davis, Mottl, and Fisher, et al., 1992).

Three samples from Site 856 were analyzed (Fig. 2a); however f'a could only be measured for two of these: a shallow immature sample,

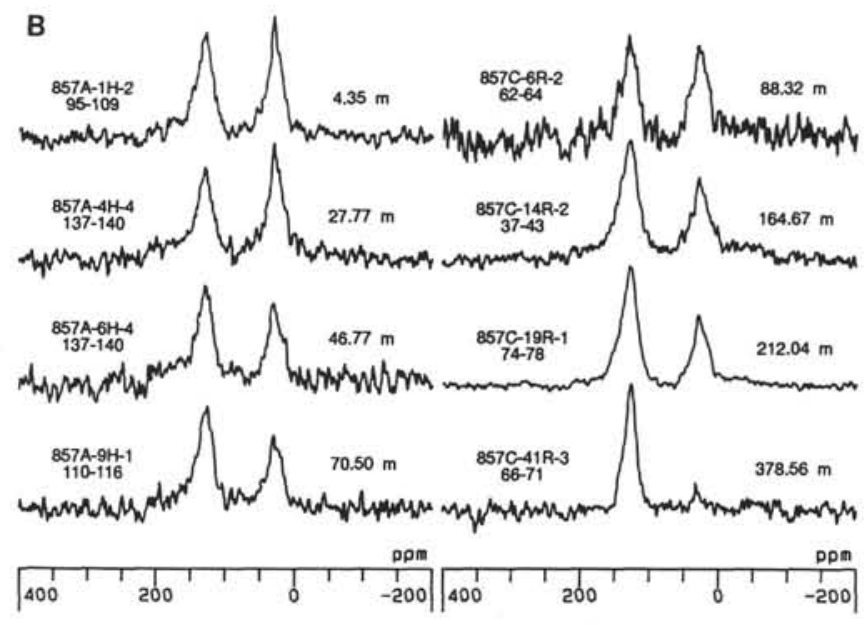

Figure 2 (continued).

$856 \mathrm{~A}-2 \mathrm{H}-5,137-140 \mathrm{~cm}(10.07 \mathrm{~m})$, with $\mathrm{f}^{\prime} \mathrm{a}=0.44$, and $856 \mathrm{~A}-13 \mathrm{X}-$ $2,143-149 \mathrm{~cm}(108.23 \mathrm{~m})$ with a high maturity f'a of 0.9 . The vitrinite reflectances within the same intervals were $R_{0}=0.4 \%$ (immature) and $2.1 \pm 0.29 \%$ (highly mature), respectively (Table 1 ).

Sample 856B-11X-1, 102-108 cm (74.32 m) in Fig. 2a is typical of many kerogens analyzed in this work which gave only a broad noisy band in the aromatic region and could not be integrated to give an $\mathrm{f}^{\prime} \mathrm{a}$ value. Other examples of this problem, which arose for some samples at all four sites, include $855 \mathrm{C}-11 \mathrm{R}-2,10-13 \mathrm{~cm}$ (96.20 m, Fig. 2a) which we believe did not undergo geothermal heating in the past (Mao et al., this volume); $857 \mathrm{C}-23 \mathrm{R}-1,5-8 \mathrm{~cm}(249.95 \mathrm{~m})$; and surface intervals in both Holes $858 \mathrm{C}$ and $858 \mathrm{D}$ (Figs. $2 \mathrm{c}$ and $2 \mathrm{a}$, respectively).

In these samples, it seems likely that paramagnetic impurities (such as iron and other metal sulfides) intimately associated with the kerogen and not removed during acid treatment during the isolation process may be responsible for degradation and broadening of the NMR signal. The problem may be aggravated by the low amounts of kerogen in the deeper sections and the admixing of significant sulfide minerals, which are almost impossible to remove without also destroying the kerogen (Durand and Nicaise, 1980). For a number of the Leg 139 kerogens, particularly those from deeper sections of Site 857 and from many Site 858 samples, a large amount of grey, presumably sulfidic residue remained after acid treatment rather than the black or brown/black residue typical of isolated kerogens.

Curiously, in some holes, the NMR signal becomes relatively strong and well resolved below these ${ }^{13} \mathrm{C}$ "wipe-out" areas. Loss of TOC was not responsible, since levels were approximately the same in samples showing and not showing the NMR "wipe-out" (Table 1). Two examples are: (1) two noisy surface samples (858D-1H-1, 0-30 $\mathrm{cm}, 0.00 \mathrm{~m}$; and $858 \mathrm{D}-2 \mathrm{H}-3,137-141 \mathrm{~cm}, 13.67 \mathrm{~m}$ ) compared with a much better resolved deeper sample, 858D-4H-3, 137-140 cm (23.12 m) (Fig. 2a); and (2) Sample 857C-23R-1, 5-8 cm (249.95 m) which shows only a weak and noisy ${ }^{13} \mathrm{C}$ NMR spectrum while the deeper and hotter $857 \mathrm{C}-41 \mathrm{R}-3,66-71 \mathrm{~cm}(378.56 \mathrm{~m})$ shows a much less noisy and better resolved aromatic region (Fig. 2b). Neither the degree of kerogen thermal alteration nor the amount of TOC seem to show any correlation with this weakening and broadening of the ${ }^{13} \mathrm{C}$ NMR signal. Likewise, on the basis of the shipboard core descriptions (Davis, Mottl, Fisher, et al., 1992), there seems to be no obvious association between the NMR signal broadening and the presence of any particular mineral.

Because of the problems in isolating kerogen in some samples, an attempt was made to measure the NMR carbon signal in $\mathrm{HCl}$ treated whole-rock samples using a large-diameter probe. However, even in immature surface samples containing relatively high abundances of TOC for this sample set $(1 \%-1.5 \%)$, no signal significantly above background noise could be obtained. 


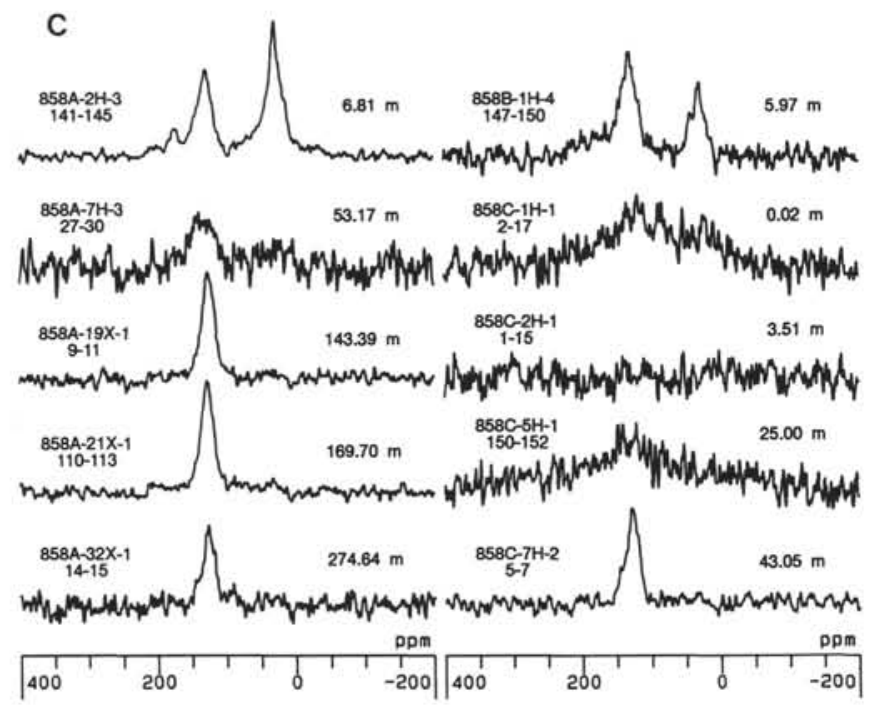

Figure 2 (continued).

At Site 857, a progressive increase in maturity with depth occurs (Fig. 3) which is reflected in an increasing $\mathrm{f}^{\prime} \mathrm{a}$ and $\% \mathrm{R}_{\mathrm{o}}$ with increasing depth and temperature. Shallow samples from 4 to $90 \mathrm{~m}$ show typical immature $\mathrm{f}^{\prime} \mathrm{a}$ values of 0.44 to 0.64 . In contrast, Sample 857C$41 \mathrm{R}-3,66-71 \mathrm{~cm}(378.56 \mathrm{~m})$ has a much higher $\mathrm{f}^{\prime} \mathrm{a}$ value $(0.91)$ and higher $R_{0}\left(1.7 \% \pm 0.12 \%\right.$; Table 1). A large increase in $f^{\prime} a$ occurs between 200 and $400 \mathrm{~m}$, consistent with the postulated past hydrothermal flow through this section (Davis, Mottl, Fisher, et al., 1992).

For Hole $858 \mathrm{~A}$, all $\mathrm{f}^{\prime}$ a values that could be measured were high (0.95), from 149 to $275 \mathrm{~m}$ (Fig. 4; Table 1). The high f'a values are consistent with the high vitrinite reflectance values $(1.5 \%$ at $150 \mathrm{~m}$, increasing to $>2.5 \%$ below $250 \mathrm{~m}$; Fig. 4 ; Mao et al, this volume). High $\mathrm{f}^{\prime} \mathrm{a}$ values were also observed for all samples measured from Holes 858B, 858C, and 858D (Fig. 4, depths all less than $50 \mathrm{~m}$ ), consistent with the active hydrothermal flow that was occurring at this site. Note Sample 858-1H-4, 147-150 cm $(5.97 \mathrm{~m})$ from the area of active hydrothermal flow has a high $\mathrm{f}^{\prime} \mathrm{a}$ value $(0.71)$, but a relatively low $R_{o}$ value $(0.45 \%$, a value just below the beginning of the oil window; Table 1). This discrepancy between $\mathrm{f}^{\prime} \mathrm{a}$ and $\mathrm{R}_{\mathrm{o}}$ is consistent with the very rapid heating this sample has undergone due to presentday active hydrothermal venting. The more rapid response of $f^{\prime} a$ to rapid heating pulses, compared with vitrinite reflectance, was previously noted by Dennis et al. (1982) and is shown by the change in slope in the correlation line between the two parameters in Fig. 8.

\section{TG-FTIR Data}

TG-FTIR data are shown in Table 1, Figures 3 through 7, and Figures 3 and 4 for Sites 857 and 858 respectively. TG-FTIR analyses of selected samples from Holes 855A, 857A and 857B, and 858A, $858 \mathrm{~B}$, and $858 \mathrm{C}$ reveal the evolution of abundant $\mathrm{NH}_{3}$ during pyrolysis of bulk sediment samples. Whelan et al. (1988) suggest that the temperature of maximum $\mathrm{NH}_{3}$ generation $\left(\mathrm{T}_{\max }\right)$ may be a useful indicator of both thermal maturity of sediments and the source of the $\mathrm{NH}_{3}$ within sediments, particularly for relatively organic lean sediments such as those from Middle Valley. Specifically, they suggest that increasing thermal maturity results in increasing $\mathrm{T}_{\max }$ for $\mathrm{NH}_{3}$. Furthermore, recent data suggest that $\mathrm{N}$ in organic matter (kerogen) is thermally released during pyrolysis at lower temperatures than $\mathrm{N}$ in inorganic minerals (Whelan et al., 1988 and unpubl. data). In support of this idea, isolated kerogens produced only one peak at relatively low temperature (about $350^{\circ}$ to $420^{\circ} \mathrm{C}$ ) while minerals containing little or no organic matter, such as organic-lean, iron-rich "red bed" samples, produce only one weak high-temperature peak with a $\mathrm{T}_{\max } \mathrm{NH}_{3}>$ about $600^{\circ} \mathrm{C}$ (Whelan, unpubl. data).

TG-FTIR profiles for many of the relatively shallow samples from Middle Valley were characterized by two distinct maxima for the $\mathrm{T}_{\max }$ of $\mathrm{NH}_{3}$ (labeled $\mathrm{T}_{\max } \mathrm{NH}_{3}(1)$ and $\mathrm{T}_{\max } \mathrm{NH}_{3}(2)$ in Table 1) while others were characterized by a single well-defined peak. In analogy to previous results, the low-temperature peak is postulated to reflect $\mathrm{NH}_{3}$ derived predominantly from organic matter while the second peak may reveal the presence of a more thermally resistant pool of N, possibly associated with inorganic phases. However, in samples characterized by a single $\mathrm{NH}_{3}$ peak where a combination of organic and inorganic sources may be contributing, it is impossible to distinguish the source of $\mathrm{N}$ solely on the basis of $\mathrm{T}_{\max }$ values. Research is in progress on samples subjected to chemical leaching to better define the types of nitrogen in each pyrolysis peak for various kinds of sediments and rocks.

Table 1 and Figures 3 and 4 reflect $\mathrm{T}_{\max }$ values for $\mathrm{NH}_{3}$ in Middle Valley sediments from Sites 857 and 858 as a function of depth. Examination of Figure 3 and Table 1 reveals a systematic increase in both $\mathrm{T}_{\max } \mathrm{NH}_{3}$ values with increasing depth at Site 857. For Hole $858 \mathrm{~A}$, one measurement was also obtained for a high $\mathrm{T}_{\max } \mathrm{NH}_{3}$ value from near the bottom of Hole 858A (Fig. 4 and Table 1), consistent with the high maturities registered by $\% \mathrm{R}_{\mathrm{o}}$ and $\mathrm{f}^{\prime} \mathrm{a}$ values in the same interval and suggestive of a $\mathrm{T}_{\max } \mathrm{NH}_{3}$ profile similar to that of Hole 857C. In Hole 858C, an abrupt increase in $\mathrm{T}_{\max } \mathrm{NH}_{3}$ occurs below the surface, consistent with the increases in the vitrinite reflectance and NMR f'a values in the same interval (Fig. 4). The profile of $\mathrm{T}_{\max } \mathrm{NH}_{3}$ values with depth is somewhat erratic for Hole $858 \mathrm{C}$, possibly because of narrow zones of lateral or localized hydrothermal flow.

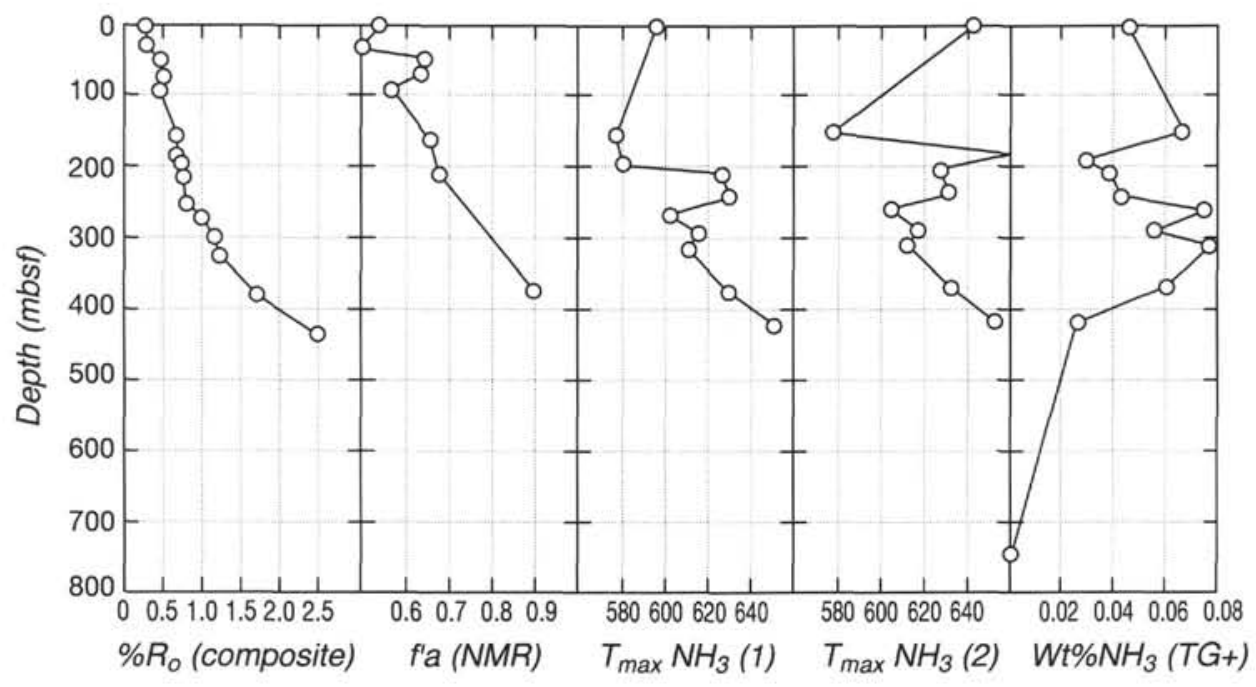

Figure 3. TG-FTIR data for Site 857. 


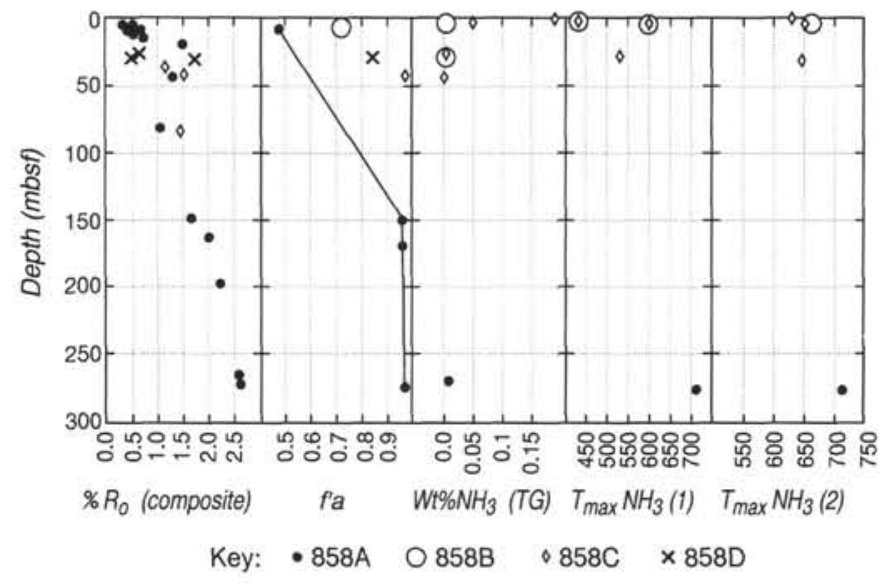

Figure 4. TG-FTIR data for Site 858.

The fraction of total nitrogen in the sediment represented by ammonia can also be obtained using the TG-FTIR technique. For the Leg 139 sediments, the weight percent (wt\%) of nitrogen in the sediments as measured by elemental analyses shows a correlation with weight lost as $\mathrm{NH}_{3}$ as measured by TG-FTIR (Fig. 6). In fact, the $\mathrm{NH}_{3}$ values measured by TG-FTIR are either equal to or slightly lower than the total nitrogen values as determined from elemental analysis, showing that most of the nitrogen in the sediments must be in the form of reduced nitrogen, i.e., as ammonia or ammonium or as organic amino groups. The wt $\%$ of pyrolyzable ammonia in these sediments also generally decreases with increased geothermal heating (Figs. 3 and 4). For example, the surface Samples 855A-3R-2, 137-140 cm (19.47 m) and $857 \mathrm{~A}-1 \mathrm{H}-2,95-109 \mathrm{~cm}(4.35 \mathrm{~m})$, which have not been heated, give $0.069 \%$ and $0.045 \% \mathrm{NH}_{3}$, respectively, while Sample $858 \mathrm{~B}-1 \mathrm{H}-$ $3,101-104 \mathrm{~cm}(4.01 \mathrm{~m})$ and $858 \mathrm{~B}-5 \mathrm{H}-3,137-140 \mathrm{~cm}(28.27 \mathrm{~m})$, which have been exposed to strong geothermal heating, show 0.0036 and $0 \mathrm{wt} \%$ ammonia, respectively. A steeply decreasing trend of weight percent of ammonia with depth and increased geothermal heating can also be observed for Hole 858C (Fig. 4 and Table 1).

$T_{\max } N_{3}(1)$ is plotted vs. $R_{o}$ for all Leg 139 samples measured to date in Figure 5. $\mathrm{T}_{\max } \mathrm{NH}_{3}$ generally increases with increasing $\mathrm{R}_{\mathrm{o}}$, but the data show considerable scatter. We suggest that changes in the minerals admixed with the kerogens may be responsible for the scatter. Previously, it has been found that $\mathrm{T}_{\max } \mathrm{NH}_{3}$ increases with increasing maturation, but that the intercepts of the lines are very dependent on the specific minerals present (Whelan et al., unpubl. data).

In addition to ammonia, methane evolution was monitored during the TG-FTIR analysis of these sediment samples. The $\mathrm{T}_{\max }$ of $\mathrm{CH}_{4}$ generation from isolated kerogens was previously found to show an excellent correlation with maturity over a wide maturity range (Whelan et al., 1990). For Middle Valley sediments, evolution of $\mathrm{CH}_{4}$ from wholerock samples (rather than kerogens) occurred continuously during progressive heating of the sample, resulting in broad complex $\mathrm{CH}_{4}$ generation curves. Unfortunately, the $\mathrm{T}_{\max }$ for $\mathrm{CH}_{4}$ from these rocks did not vary systematically with depth or any other maturation dependent parameter (Fig. 7), although there does appear to be a general increase with $\mathrm{R}_{\mathrm{o}}$ at higher maturities. Part of the scatter is probably produced by mineral matrix effects in these low TOC samples. Measurements on isolated kerogens, which eliminate this problem (Whelan et al., 1990), have not yet been carried out.

No longer-chain hydrocarbons (tars, paraffins, etc.) were observed during pyrolysis of these rock samples. Similar results have been observed previously with low TOC samples where amounts and $\mathrm{T}_{\max }$ values of "tar" (i.e., the sum of hydrocarbons larger than methane) and methane were obtainable only on isolated kerogens and not on wholerock samples (Whelan et al., 1988 and 1990). Work is in progress to carry out TG-FTIR measurements on isolated kerogens from Leg 139 samples.

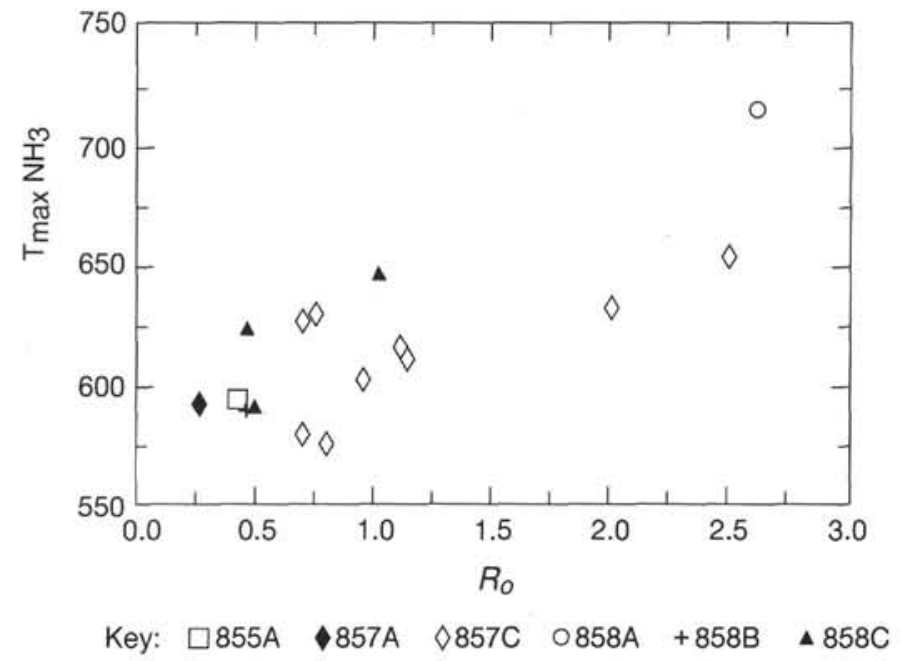

Figure 5. TG-FTIR data for Leg 139: $\mathrm{T}_{\max } \mathrm{NH}_{3}$ vs. vitrinite reflectance $\left(\% \mathrm{R}_{\mathrm{o}}\right)$.

\section{DISCUSSION}

\section{Source of Nitrogen in Leg 139 Sediments}

Increasing $\mathrm{T}_{\max } \mathrm{NH}_{3}(1)$ for $\mathrm{NH}_{3}$ from $423^{\circ}$ to $714^{\circ} \mathrm{C}$ with increasing thermal maturity is consistent with derivation of the ammonia nitrogen from pyrolytic degradation of organic matter. The degradation of organic matter is a function of both time and temperature, although at Middle Valley, temperature may be the dominant variable owing to the geologically young age of the sediments and the high temperatures associated with basaltic volcanism at mid-ocean ridges. During progressive maturation of sediments, the weakest bonds within the organic matter are broken first. Liquid and gaseous alteration products are removed and residual solid material becomes increasingly resistant to thermal degradation, which in turn is reflected by higher $\mathrm{T}_{\max }$ for $\mathrm{NH}_{3}$ during pyrolysis. For example, the extremely low $\mathrm{T}_{\max }$ value for $\mathrm{NH}_{3}$ of the shallowest sample from Hole $858 \mathrm{C}$, which was essentially collected at the seafloor, probably reflects a high abundance of nitrogen as proteinaceous material not yet destroyed by diagenetic and hydrothermal processes. Because proteinaceous material is easily degraded by heating, maximum $\mathrm{NH}_{3}$ evolution occurs at relatively low temperatures. The majority of organic $\mathrm{N}$ in deeper samples, however, is likely increasingly contained in various NSO compounds in generated bitumen and kerogen components. As these become increasingly bound into the residual kerogen and mineral matrix via heterocyclic groups and crosslinking, resistance to thermal degradation and consequently maximum $\mathrm{NH}_{3}$ generation occurs at higher temperatures.

$\mathrm{T}_{\max } \mathrm{NH}_{3}(2)$ also shows increasing $\mathrm{T}_{\max }$ values with increasing maturity (Fig. 3), suggesting that a significant portion of this nitrogen, as well, may be derived from organic matter. Similar arguments may apply to sediment samples characterized by only a single $\mathrm{NH}_{3}$ peak, where an increasing $\mathrm{T}_{\max }$ with increasing maturation is also observed. Alternatively, the increases in $\mathrm{T}_{\max } \mathrm{NH}_{3}$ could also represent the increasing proportion of minerals with increased stability under pyrolysis conditions in the more mature sections. Such an alteration might explain the maximum in $\mathrm{T}_{\max } \mathrm{NH}_{3}(2)$ observed from 200 to $300 \mathrm{mbsf}$ in Hole $857 \mathrm{C}$ (Fig. 3), a zone highly influenced by lateral hydrothermal flow (Davis, Mottl, Fisher, et al., 1992).

\section{Relationship of NMR and Vitrinite Reflectance Data to Geothermal Temperature}

NMR f'a values correlate reasonably well with vitrinite reflectance values (Fig. 8) and the Leg 139 points lie fairly close to the correlation line previously defined for basaltic intrusions into Creta- 
Table 2. Maximum past temperatures of Leg 139 samples based on NMR f́a and \%Ro values compared with data of Barker (1983), Barker and Pawlewicz (1986), and Sweeney and Burnham (1990).

\begin{tabular}{|c|c|c|c|c|c|c|c|c|c|c|}
\hline \multirow{2}{*}{$\begin{array}{l}\text { Core, section, } \\
\text { interval }(\mathrm{cm})\end{array}$} & \multirow{2}{*}{$\begin{array}{l}\text { Depth } \\
\text { (mbsf) }\end{array}$} & \multirow{2}{*}{$\begin{array}{c}\text { \%Ro } \\
\text { (composite) }\end{array}$} & \multirow[b]{2}{*}{$f^{\prime} a$} & \multirow{2}{*}{$\begin{array}{l}\text { Estimated present } \\
\text { geothermal } \\
\text { temperatures }\end{array}$} & \multirow{2}{*}{$\begin{array}{l}\text { Past maximum } \\
\text { temperatures } \\
\qquad\left({ }^{18} \mathrm{O}\right)\end{array}$} & \multirow{2}{*}{$\begin{array}{l}\text { Estimated } \\
\text { from Barker } \\
\text { (1983) }\end{array}$} & \multirow{2}{*}{$\begin{array}{c}\text { Estimated } \\
\text { from Barker } \\
\text { and Pawlewicz (1986) }\end{array}$} & \multicolumn{3}{|c|}{$\begin{array}{l}\text { Estimated from Sweeney and } \\
\text { Bumbam (1990) Heating rate }\end{array}$} \\
\hline & & & & & & & & $1^{\circ} \mathrm{C} / 1000 \mathrm{yr}$ & $10^{\circ} \mathrm{C} / \mathrm{yr}$ & $5^{\circ} \mathrm{C} / \mathrm{m} . \mathrm{y}$. \\
\hline $\begin{array}{l}\text { 139-855C- } \\
\text { IR-2, 141-144 }\end{array}$ & 2.91 & 0.3 & 0.56 & & & $<20$ & 40 & 75 & 150 & 50 \\
\hline $\begin{array}{l}139-856 \mathrm{~A}- \\
\quad 2 \mathrm{H}-4,86-101 \\
13 \mathrm{X}-2,143-149\end{array}$ & $\begin{array}{r}8.06 \\
108.23\end{array}$ & $\begin{array}{c}0.4 \\
>2.58\end{array}$ & $\begin{array}{l}0.63 \\
0.9\end{array}$ & & & $\begin{array}{l}<20 \\
261\end{array}$ & $\begin{array}{r}70 \\
>280\end{array}$ & $\begin{array}{r}110 \\
>260\end{array}$ & $\begin{array}{r}180 \\
>360\end{array}$ & $\begin{array}{r}75 \\
>220\end{array}$ \\
\hline $\begin{array}{l}139-857 \mathrm{~A}- \\
1 \mathrm{H}-2,95-109 \\
4 \mathrm{H}-4,137-140 \\
6 \mathrm{H}-4,137-140 \\
9 \mathrm{H}-1,110-116\end{array}$ & $\begin{array}{r}4.35 \\
27.77 \\
46.77 \\
70.50\end{array}$ & $\begin{array}{l}0.2 \\
0.2 \\
0.38 \\
0.42\end{array}$ & $\begin{array}{l}0.53 \\
0.51 \\
0.64 \\
0.63\end{array}$ & $\begin{array}{r}<30 \\
<30 \\
60 \\
70\end{array}$ & $\begin{array}{l}<30 \\
<30 \\
30\end{array}$ & $\begin{array}{l}<20 \\
<20 \\
<20\end{array}$ & $\begin{array}{l}30 \\
50\end{array}$ & $\begin{array}{r}30 \\
30 \\
100 \\
120\end{array}$ & $\begin{array}{r}90 \\
90 \\
175 \\
190\end{array}$ & $\begin{array}{l}20 \\
20 \\
70 \\
80\end{array}$ \\
\hline $\begin{array}{l}\text { 139-857C- } \\
6 \mathrm{R}-2,62-64 \\
41 \mathrm{R}-3,66-71 \\
53 \mathrm{R}-1,27-30\end{array}$ & $\begin{array}{r}88.32 \\
378.56 \\
433.07\end{array}$ & $\begin{array}{c}0.4 \text { to } 0.6 \\
1.7 \\
>2.5\end{array}$ & $\begin{array}{l}0.56 \\
0.91 \\
\text { ND }\end{array}$ & $\begin{array}{r}65 \\
225 \\
260\end{array}$ & $\begin{array}{r}40 \\
210 \\
260\end{array}$ & $\begin{array}{r}20 \\
200 \\
256\end{array}$ & $\begin{array}{l}70 \text { to } 90 \\
225 \\
>270\end{array}$ & $\begin{array}{l}110 \text { to } 150 \\
240 \\
>260\end{array}$ & $\begin{array}{l}180 \text { to } 225 \\
325 \\
>360\end{array}$ & $\begin{array}{l}75 \text { to } 110 \\
190 \\
>220\end{array}$ \\
\hline $\begin{array}{l}\text { 139-858B- } \\
\quad 1 \mathrm{H}-3,101-104\end{array}$ & 4.01 & 0.3 to 0.45 & 0.71 & 40 & & $<20$ & $<20$ to 60 & 75 to 130 & 150 to 200 & 50 to 90 \\
\hline
\end{tabular}

Notes: $\mathrm{ND}=$ not determined; $\% \mathrm{R}_{\mathrm{o}}$ (composite)s from both TAI and vitrinite reflectance (see text). Estimated present geothermal temperatures taken from Davis et al. (this volume) and Davis, Mottl, Fisher, et al., (1992). Past temperatures from Boni et al. and Baker et al. (both in this volume). Estimates from Barker (1983) were determined by means of regression equation $R_{\mathrm{m}}=0.435 \mathrm{e}^{(0.00683 \mathrm{~T})}$.

Table 3. Estimate of maximum temperature of Leg 139 samples, based on $R_{0}-T$ calibrations other than those in Table 2.

\begin{tabular}{|c|c|c|c|c|c|c|c|c|}
\hline \multirow[b]{4}{*}{$\begin{array}{l}\text { Core, section, } \\
\text { interval }(\mathrm{cm})\end{array}$} & \multirow[b]{4}{*}{$\begin{array}{l}\text { Depth } \\
\text { (m) }\end{array}$} & \multirow[b]{4}{*}{$\begin{array}{c}\% \mathrm{R}_{\mathrm{o}} \\
\text { (composite) }\end{array}$} & \multirow[b]{4}{*}{$\underset{f^{\prime} a}{\text { NMR }}$} & \multicolumn{5}{|c|}{ Estimated temperatures $\left(\mathrm{T},{ }^{\circ} \mathrm{C}\right.$, see text) } \\
\hline & & & & \multicolumn{4}{|c|}{ From Dennis et al. (1982) } & \multirow{3}{*}{$\begin{array}{c}\begin{array}{c}\text { From Bostik } \\
\text { (1971) }\end{array} \\
\begin{array}{c}\text { T estimated } \\
\text { from: }\end{array} \\
\% \mathrm{R}_{\mathrm{o}} \\
\text { (composite) }\end{array}$} \\
\hline & & & & \multicolumn{2}{|c|}{$\begin{array}{c}\text { Field data; } \mathrm{T} \\
\text { estimated from: }\end{array}$} & \multicolumn{2}{|c|}{$\begin{array}{c}\text { Laboratory heating } \\
\text { data; } T \text { estimated from: }\end{array}$} & \\
\hline & & & & $\begin{array}{c}\% \mathrm{R}_{\mathrm{o}} \\
\text { (composite) }\end{array}$ & $f^{\prime} a$ & $\begin{array}{c}\% \mathrm{R}_{\mathrm{o}} \\
\text { (composite) }\end{array}$ & $f^{\prime} a$ & \\
\hline $\begin{array}{l}\text { 139-855A- } \\
\quad \text { IR-2, } 141-144\end{array}$ & 2.91 & 0.3 & 0.56 & 100 & 125 & $=300$ & 300 & 30 \\
\hline $\begin{array}{l}139-856 \mathrm{~A}- \\
\quad 2 \mathrm{H}-4,86-101 \\
\quad 13 \mathrm{X}-2,143-149\end{array}$ & $\begin{array}{r}8.06 \\
108.23\end{array}$ & $\begin{array}{c}0.4 \\
>2.58\end{array}$ & $\begin{array}{l}0.63 \\
0.9\end{array}$ & $\begin{array}{r}125 \\
>475\end{array}$ & $\begin{array}{l}145 \\
400\end{array}$ & $\begin{array}{l}301 \\
500\end{array}$ & $\begin{array}{l}325 \\
490\end{array}$ & $\begin{array}{r}45 \\
>145\end{array}$ \\
\hline $\begin{array}{l}139-857 \mathrm{~A}- \\
1 \mathrm{H}-2,95-109 \\
6 \mathrm{H}-4,137-140 \\
9 \mathrm{H}-1,110-116\end{array}$ & $\begin{array}{r}4.35 \\
46.77 \\
70.50\end{array}$ & $\begin{array}{l}0.2 \\
0.38 \\
0.42\end{array}$ & $\begin{array}{l}0.53 \\
0.64 \\
0.63\end{array}$ & $\begin{array}{r}50 \\
120 \\
125\end{array}$ & $\begin{array}{l}115 \\
150 \\
145\end{array}$ & $\begin{array}{l}300 \\
335 \\
330\end{array}$ & $\begin{array}{l}305 \\
325 \\
320\end{array}$ & $\begin{array}{l}<30 \\
=40 \\
=50\end{array}$ \\
\hline $\begin{array}{l}139-857 \mathrm{C}- \\
6 \mathrm{R}-2,62-64 \\
41 \mathrm{R}-3,66-71 \\
53 \mathrm{R}-1,27-30\end{array}$ & $\begin{array}{r}88.32 \\
378.56 \\
433.07\end{array}$ & $\begin{array}{c}0.4 \text { to } 0.6 \\
1.7 \\
>2.5\end{array}$ & $\begin{array}{l}0.56 \\
0.91 \\
\text { ND }\end{array}$ & $\begin{array}{c}120 \text { to } 200 \\
375 \\
>440\end{array}$ & $\begin{array}{l}125 \\
400 \\
\text { ND }\end{array}$ & $\begin{array}{l}305 \\
520 \\
\text { ND }\end{array}$ & $\begin{array}{l}300 \\
495 \\
\text { ND }\end{array}$ & $\begin{array}{c}45 \text { to } 60 \\
123\end{array}$ \\
\hline $\begin{array}{l}\text { 139-858B- } \\
\quad 1 \mathrm{H}-3,101-104\end{array}$ & 4.01 & 0.3 to 0.45 & 0.71 & 98 to 135 & 250 & 350 & 360 & 30 to 45 \\
\hline
\end{tabular}

Notes: \% $\mathrm{R}_{\mathrm{o}}$ (composite) from Table $1 . \mathrm{ND}=$ not determined.

ceous sapropelic organic-rich South Atlantic sediments recovered on DSDP Leg 41 (Dennis et al., 1982; Peters et al., 1978).

Two types of $\mathrm{R}_{\mathrm{o}}$ values were used for the "\% $\mathrm{R}_{0}$ (composite)" axis in Figs. 3, 4, and 8 in order to obtain reliable $R_{o}$ values in all maturity ranges. In Tables $1-3$, " $\mathrm{R}_{0} \%$ (vit refle)" in Table 1 was obtained by measuring reflectance of the vitrinite maceral; " $R_{0}$ equiv" was calculated from thermal alteration indices (TAI) on spores (Mao et al., this volume). At low $R_{o}$ values, below $R_{o}=0.4 \%$, a $R_{0}$ calculated from TAI is more reliable while direct measurement of $R_{0}$ gives a better indication of maturity at $R_{o}>0.4 \%$ (Jones and Edison, 1979).

NMR $f^{\prime}$ a values are generally low $(<0.6)$ for immature Leg 139 samples $\left(R_{0}<0.5 \%\right)$, such as those from shallow sections of Holes $855 \mathrm{~A}$ and $857 \mathrm{~A}$ (Tables $1-3$ ). The NMR $\mathrm{f}^{\prime} \mathrm{a}$ values increase to typical high-maturity values of about 0.9 in Sample $857 \mathrm{C}-41 \mathrm{R}-1,66-71 \mathrm{~cm}$
$(378.56 \mathrm{~m})$, which also has a relatively high $\mathrm{R}_{\mathrm{o}}$ value of $1.7 \pm 0.19 \%$, typical of kerogens beyond the oil window in the gas condensate and starting into the dry gas window (Mao et al., this volume).

It is interesting that Sample $855 \mathrm{C}-11 \mathrm{R}-2,10-13 \mathrm{~cm}$ from near the bottom of Hole $855 \mathrm{C}(96.20 \mathrm{~m})$ shows predominantly a broad and weak aromatic NMR signal (Fig. 2a) even though there is no evidence of geothermal heating $\left(\mathrm{R}_{\mathrm{o}}=0.4 \%\right.$, Table 1 ; Mao et al., this volume). We postulate that the low abundance of aliphatic carbon atoms in this interval may be due to cold recharging seawater flowing into this section from the basement rocks below. Such a flow of oxygenated water, which may also contain microbial nutrients, would allow any aerobic bacteria present either in the water or the sediments to degrade the residual organic matter. Previous research has shown that microorganisms in deep sediments as old as $110,000 \mathrm{yr}$ can be reactivated 
Leg 139

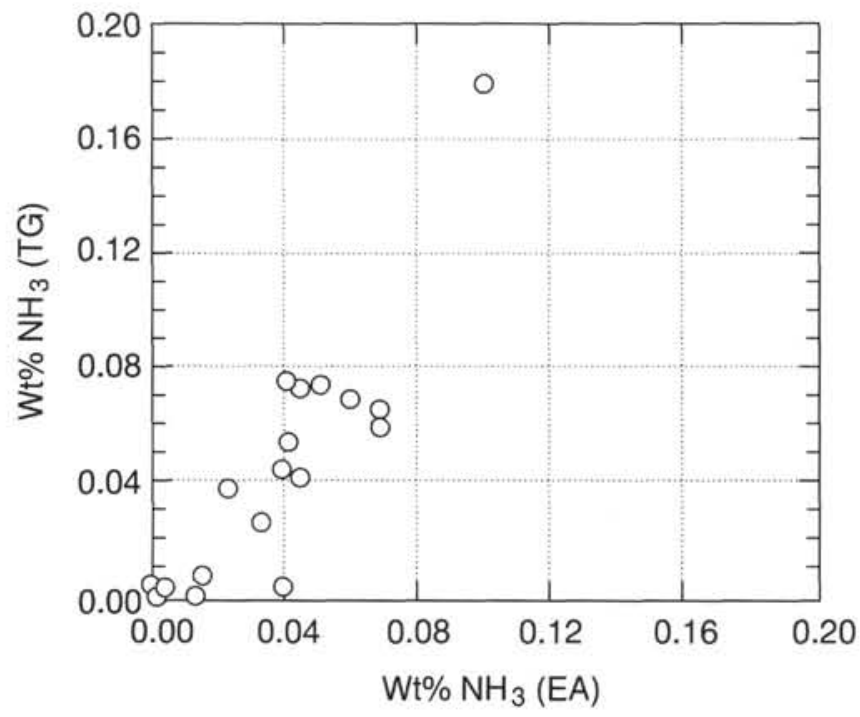

Figure 6. Wt\% of $\mathrm{NH}_{3}$ from TG-FTIR plotted vs. the same measurement made via elemental analysis (EA).

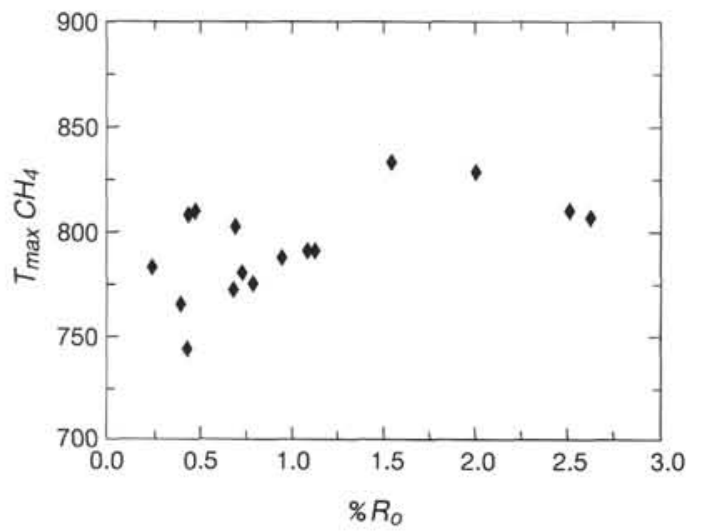

Figure 7. TG-FTIR data for Leg 139: $\mathrm{T}_{\max }$ methane vs. percent vitrinite reflectance $\left(\% \mathrm{R}_{\mathrm{o}}\right)$.

if proper nutrients are provided (Whelan et al., 1986). In addition, microbial degradation in sediments preferentially destroys the aliphatic over the aromatic part of kerogen (Tarafa et al., 1987).

Because of the reasonably good correlation between $f^{\prime} a$ and $R_{o}$ in the combined plot for the Leg 41 and Leg 139 samples (Fig. 8), an attempt was made to estimate the maximum temperature exposure of Leg 139 kerogens by comparison to $\mathrm{R}_{\mathrm{o}}$ and $\mathrm{f}^{\prime} \mathrm{a}$ values from the Leg 41 samples (Dennis et al., 1982). The results are shown in Table 3. Two different sets of temperatures are shown, one derived from laboratory heating experiments of Leg 41 kerogens (listed as "laboratory" in Table 3) and the other derived from "field data," using estimated well temperatures from Peters et al. (1978) and Bostik (1971). For comparison, estimated present geothermal temperatures are shown in Table 2, based on downhole temperature measurements (Davis, Mottl, and Fisher, et al., 1992) and modeling by Davis and Wang (this volume) and maximum past temperatures as estimated from $\delta^{18} \mathrm{O}$ measurements (Boni et al., this volume; Baker et al., this volume). Both of the estimated maximum well temperatures based on the Leg 41 calibrations (Table 3 ) are much higher than the present-day measured values (Table 2). In fact, the maximum temperature exposures estimated from the Leg 41 heating experiments, in the range of $300^{\circ} \mathrm{C}$ even for immature surface samples (e.g., Samples $855 \mathrm{C}-1 \mathrm{R}-2$, $141-144 \mathrm{~cm}, \mathrm{R}_{\mathrm{o}}=0.3 \%$, and $857 \mathrm{~A}-1 \mathrm{H}-2,95-109 \mathrm{~cm}, \mathrm{R}_{\mathrm{o}}=0.2 \%$;

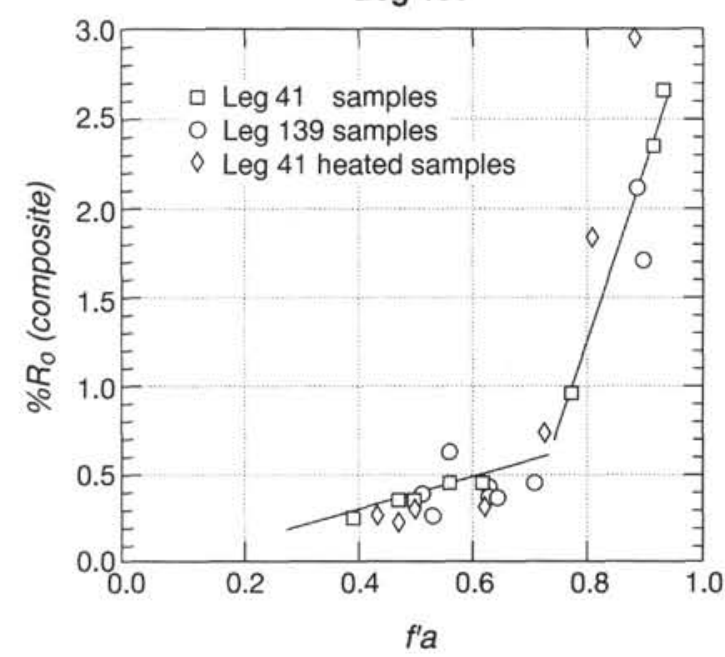

Figure 8. NMR aromaticity, $f^{\prime}$ a vs. vitrinite reflectance $\left(\% R_{o}\right), L$ eg 41 and Leg 139 samples. The two lines represent the correlation lines for the Leg 41 well samples (from Dennis et al., 1982).

Table 3), seem geologically unreasonable. The calculated temperatures estimated from the Leg 41 well calibration set are lower (Table 3 ), but still seem high, particularly for the immature samples.

We propose that the maximum temperature exposures derived from both sets of the Leg 41 data (Table 3) are too high and that other $R_{0}$ vs. maximum temperature calibration sets of Barker (1983), Barker and Pawlewicz (1986) and Sweeney and Burnham (1990) provide more realistic estimates of maximum heating of the Leg 139 samples, as shown in Table 2 and discussed below.

Several researchers have discussed the problem of using laboratory heating experiments as a calibration for estimating maximum geologic temperatures, even for hydrothermal systems where geologic heating times are relatively short (Barker, 1983 and 1991; Barker and Pawlewicz, 1986; Sweeney and Burnham, 1990). Barker postulates, based on earlier work of Hood et al. (1975), that the time the sample spends within $15^{\circ} \mathrm{C}$ of its maximum temperature is the critical parameter in setting the vitrinite reflectance values and that this time is relatively short even for slowly buried sediments. However, if heating times are very short, as is the case in laboratory heating experiments, then the kerogen has insufficient time to react and produce a steady-state $R_{o}$ value characteristic of that particular temperature. With somewhat longer reaction times, such as those in hydrothermal systems that heat at an average rate of about $1^{\circ} \mathrm{C} / 1000 \mathrm{yr}$ (Barker, 1983; 1991), the kerogen vitrinite reaction does have time to reach its stable state at a specific temperature. In addition, Barker and Pawlewicz (1986) have shown that heating times longer than the critical required amount at a particular temperature have no further influence in changing the vitrinite reflectance value beyond the scatter from the initial $R_{o}$ and well temperature measurements. Therefore, they postulated that vitrinite reflectance is an excellent indicator of maximum temperature exposure in cases where $R_{0}$ values and downhole temperature measurements of both the sample and the calibration data sets are well constrained.

Sweeney and Burnham (1990 and references cited) have developed a method for calculating vitrinite reflectance values which they show to be applicable to a variety of geologic systems, including the hydrothermal systems discussed by Barker $(1983 ; 1991)$. They conclude that temperature is generally more important than time, but that both have an influence and that time is particularly important in cases with short heating times.

The maximum temperature exposures for the Leg 139 samples were estimated using calibration data of Barker (1983), Barker and Pawlewicz (1986) and Sweeney and Burnham (1990) and are compared to the Leg 139 present-day temperature measurements in Table 2. In all cases, except for that utilizing the very high heating rate 
$\left(10^{\circ} \mathrm{C} / \mathrm{yr}\right)$ from Sweeney and Burnham (1990) the estimated past maximum temperatures are close to the estimated present-day values. The two sets of values from Barker utilize very different kerogen types. Barker (1983) uses data from several liquid-dominated hydrothermal systems with both $\mathrm{R}_{\mathrm{o}}$ and temperature measurements coming from Barker's laboratory; Barker and Pawlewicz (1986) develop the $\mathrm{R}_{\mathrm{o}}$ /temperature correlation from a data set with much more scatter, which includes a wide variety of literature data on humic kerogens covering many wells and heating rates. The latter calibration set gives an excellent match to the present-day temperatures estimated for the Leg 139 samples in spite of the considerable scatter in the Barker and Pawlewicz (1986) plot due to the measurements being collected from many different laboratories. Using the Barker (1983) and Barker and Pawlewicz (1986) calibrations, maximum temperature exposures of Samples 855A-1R-2, 141-144 cm (2.91 m), 856A-2H-4, 86-101 cm $(8.06 \mathrm{~m})$, and 856A-13X-2, 143-149 cm (108.23 m), where downhole temperature information is not available, can be estimated to have been $40^{\circ} \mathrm{C}, 70^{\circ} \mathrm{C}$, and $>280^{\circ} \mathrm{C}$, respectively.

Data of Sweeney and Burnham (1990) do not give as good a match to present-day temperatures. In particular, maximum temperatures calculated for the 46 to $88 \mathrm{~m}$ intervals of Holes $857 \mathrm{~A}$ and $857 \mathrm{C}$ using the higher heating rates $\left(1^{\circ} \mathrm{C} / 1000 \mathrm{yr}\right.$, and $\left.10^{\circ} \mathrm{C} / \mathrm{yr}\right)$ are considerably higher than present-day measured values. In addition, the highest heating rate calibration curve of Sweeney and Burnham gives maximum temperatures that appear to be too high for the immature Hole $857 \mathrm{~A}$ surface samples. Of the three different heating rates from Sweeney and Burnham (1990) used in Table 2, the slowest of $5^{\circ} \mathrm{C} / \mathrm{m}$.y. reproduces the present-day Leg 139 temperatures best for all except the deepest and hottest Leg 139 samples. However, on the basis of data in Davis and Wang (this volume) and Davis, Mottl, Fisher, et al. (1992), the Sweeney and Burnham (1990) curve for the more rapid heating rates of at least $1^{\circ} \mathrm{C} / 1000 \mathrm{~m}$ are closer to the actual average geothermal gradient of about $2.24^{\circ} \mathrm{C} / 1000 \mathrm{~m}$ measured for Hole $857 \mathrm{C}$, suggesting that in the past, several intervals have been hotter than they are at the present time.

None of the sediments examined in this work, with the possible exception of those at Site 856, were older than Pleistocene, so that heating times are short on a geologic time scale. Davis and Wang (this volume) estimate that Site 857 sediments were heated at close to their current temperature maximum of $280^{\circ} \mathrm{C}$ for most of the past 125,000 $\mathrm{yr}$, giving a heating rate at this site of $2.24^{\circ} \mathrm{C} / 1000 \mathrm{yr}$. In the active shallower hydrothermal system at Site 858 , maximum temperature is estimated to be about the same as deeper values for Site 857, except that hydrothermal fluids are currently penetrating very close to the ocean floor so that heating times for some intervals are probably very short, perhaps less than 10 years.

Maximum temperatures were also estimated from data in Bostick (1971), but appear to be too low in comparison with present-day measurements (Table 3).

Humic kerogen and hydrothermal well data have been used to replicate present-day temperatures of Leg 139 samples, as shown in Table 2. The excellent match suggests why the temperature estimates using the Leg 41 kerogen $R_{o}$ and $f^{\prime} a$ values of Dennis et al. (1982) are probably too high. Part of the problem may be discrepancies in heating rates, with the Leg 41 kerogens being heated much more rapidly by an igneous intrusion, compared with the Leg 139 samples, which were heated more slowly by the underlying hydrothermal system. In addition, maturation rates of the very different kerogen types are being compared. Leg 41 kerogens typically are sapropelic and organic rich; Leg 139 sediments contain lower amounts of typically more oxidized type III kerogens (Mao et al., this volume). For the NMR data, this means that the initial starting NMR $\mathrm{f}^{\prime}$ a value for the Leg 41 values is much lower than for Leg 139 samples ( 0.2 compared to 0.5$)$. Also, the hydrogen-rich liptinitic nature of the Leg 41 samples may be suppressing and artificially lowering their vitrinite reflectance values (Walker et al., 1983). Similar suppression would not be expected for the less hydrogen-rich Leg $139 \mathrm{R}_{\mathrm{o}}$ values, so that using Leg 41 as a calibration

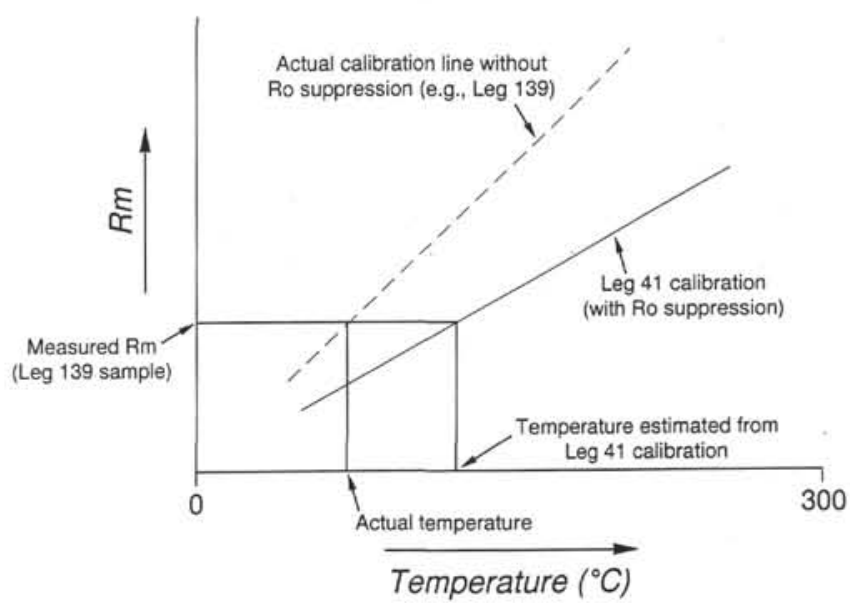

Figure 9. Schematic diagram showing how calibration line of $R_{0}$ vs. temperature using suppressed vitrinite values (e.g., sapropelic kerogens such as those from Leg 41) would cause overestimates of maximum well temperatures when applied to nonsuppressed (i.e., more humic) kerogens, such as those recovered on Leg 139.

set could produce artificially high calculated maximum temperatures for Leg 139 kerogens, as shown in Figure 9.

\section{CONCLUSIONS}

1. At Site 857 , a progressive increase in maturity with depth to $379 \mathrm{~m}$ is reflected by increasing ${ }^{13} \mathrm{C}$ NMR aromaticity values ( $\left.f^{\prime} \mathrm{a}\right)$ along with an increase in $\% \mathrm{R}_{\mathrm{o}}$ and downhole temperature. Shallow samples from 4 to $90 \mathrm{~m}$ show typically immature $\mathrm{f}^{\prime} \mathrm{a}$ values of 0.5 to 0.64 while Sample $857 \mathrm{C}-41 \mathrm{R}-3,66-71 \mathrm{~cm}$ at $378.56 \mathrm{~m}$ has a typical high maturity $\mathrm{f}^{\prime} \mathrm{a}$ value of 0.91 . A large increase in $\mathrm{f}^{\prime} \mathrm{a}$ occurs between 200 and $379 \mathrm{~m}$, consistent with the postulated past hydrothermal flow through this section.

2. At Site 858 , only high maturity $f^{\prime}$ a values $(>0.9)$ occurred below $150 \mathrm{~m}$ in Hole $858 \mathrm{~A}$, consistent with the high vitrinite reflectance values $(>1.5)$ in the same interval. High $\mathrm{f}^{\prime} \mathrm{a}$ values are also observed for shallow sections ( $<50 \mathrm{mbsf}$ ) of Holes $858 \mathrm{~B}, 858 \mathrm{D}$, and $858 \mathrm{C}$, consistent with active hydrothermal flow in these holes.

3. NMR f'a values correlate reasonably well with vitrinite reflectance values and the Leg 139 points lie fairly close to the correlation line previously defined for basaltic intrusions into Cretaceous sapropelic organic-rich South Atlantic sediments recovered on DSDP Leg 41. However, maximum temperatures estimated for Leg 139 samples using the Leg 41 temperature $/ f^{\prime} a / R_{o}$ data as a calibration are much higher than present-day temperatures and seem geologically unreasonable. We postulate that the problem arises from the very different kerogen types present in organic-lean sediments from Leg 139 vs. organic-rich sapropelic sediments present at Leg 41 in the Southeast Atlantic. A second problem may be introduced by using laboratory heating experiments as a calibration for estimating maximum geologic temperatures, even for hydrothermal systems where geologic heating times are relatively short.

4. Other $R_{0}$ vs. maximum temperature calibration sets of Barker (1983), Barker and Pawlewicz (1986) and Sweeney and Burnham (1990) provide estimates of maximum heating of the Leg 139 samples: for Hole $857 \mathrm{C}$, less than $30^{\circ} \mathrm{C}$ at depths shallower than $47 \mathrm{~m}$; $200^{\circ}$ to $225^{\circ} \mathrm{C}$ at $378 \mathrm{~m}$; and $256^{\circ}$ to $>270^{\circ} \mathrm{C}$ at $433 \mathrm{~m}$. These values closely match present-day downhole measured temperatures of $<30^{\circ} \mathrm{C}, 210^{\circ}$ to $225^{\circ} \mathrm{C}$, and $260^{\circ} \mathrm{C}$, respectively. Maximum temperature exposures for other Leg 139 samples for which downhole measurements were not available were estimated to be in the range of $<20^{\circ}$ to $40^{\circ} \mathrm{C}$ for $855 \mathrm{C}-1 \mathrm{R}-2$ at $2.91 \mathrm{~m} ;<20^{\circ}$ to $70^{\circ} \mathrm{C}$ for $856 \mathrm{~A}-2 \mathrm{H}-4$ at $8.06 \mathrm{~m}$; and $261^{\circ}$ to $>280^{\circ} \mathrm{C}$ for Sample $856 \mathrm{~A}-13 \mathrm{X}-2$ at $108.23 \mathrm{~m}$. 
5. TG-FTIR profiles for several Middle Valley rocks were characterized by two distinct temperature maxima for maximum evolution of ammonia, $\mathrm{T}_{\max } \mathrm{NH}_{3}(1)$ and $\mathrm{T}_{\max } \mathrm{NH}_{3}(2)$. In some cases, the two peaks overlapped to produce a single well-defined peak. We postulate that the low-temperature peak reflects $\mathrm{NH}_{3}$ derived predominantly from organic matter, while the second peak may reflect the presence of a more thermally resistant pool of $\mathrm{N}$, possibly associated with inorganic phases, as well as associated organic matter. Both $\mathrm{T}_{\max } \mathrm{NH}_{3}$ values showed a general increase with increasing thermal maturity and maximum temperature exposure. Simultaneously, the total wt $\%$ of ammonia in the rocks decreased. We postulate that scatter in the $\mathrm{T}_{\max } \mathrm{NH}_{3}$ trends is caused by changes in the mineral matrix. Specifically, the presence of an increasing proportion of more thermally stable minerals might explain the maxima in $\mathrm{T}_{\max } \mathrm{NH}_{3}(2)$ profiles observed from 200 to 300 mbsf in Hole $857 \mathrm{C}$, a zone influenced by lateral hydrothermal flow.

6. For Hole $857 \mathrm{C}, \mathrm{T}_{\max }$ for $\mathrm{NH}_{3}$ increases from $575^{\circ} \mathrm{C}$ at $154.6 \mathrm{~m}$ to $652^{\circ} \mathrm{C}$ at $433.0 \mathrm{~m}$, consistent with a substantial increase in thermal maturity within this interval, as is also reflected in both the vitrinite reflectance and ${ }^{13} \mathrm{C}$ NMR $\mathrm{f}^{\prime}$ a values. Hole $858 \mathrm{C}$ shows a similar trend for $\mathrm{T}_{\max } \mathrm{NH}_{3}(1)$, but with the gradient increasing much more steeply. One measurement was also obtained from near the bottom of Hole $858 \mathrm{~A}$, showing a high $\mathrm{T}_{\max } \mathrm{NH}_{3}$ value, consistent with the high maturities registered by $\% \mathrm{R}_{\mathrm{o}}$ and $\mathrm{f}^{\prime} \mathrm{a}$ values.

7. The wt $\%$ of nitrogen in the sediments as measured by elemental analyses shows an excellent correlation with weight lost as $\mathrm{NH}_{3}$ as measured by TG-FTIR. Comparison of the TG-FTIR and elemental analysis data suggests that most of the nitrogen in these sediments is present as reduced nitrogen (i.e., as ammonia or ammonium or as organic amino groups), and is increasingly incorporated into kerogen heterocyclic compounds or the mineral matrix at higher maturities.

8. $\mathrm{T}_{\max }$ for $\mathrm{CH}_{4}$ from whole rocks did not vary systematically with maturation, although there does appear to be a general increase with $R_{o}$ at higher maturities $\left(R_{0}>1 \%\right)$. No longer-chain hydrocarbons ("tars") were observed during pyrolysis of these relatively organic lean-rock samples (TOC generally $<0.5$ to $1 \%$ ).

9. We postulate that the low abundance of aliphatic relative to aromatic carbon atoms in kerogens isolated from geothermally cold Hole $855 \mathrm{C}$ is caused by the flow of cold recharging oxygenated seawater into this section, which causes preferential biodegradation of aliphatic parts of the kerogen by aerobic bacteria.

\section{ACKNOWLEDGMENTS}

Thanks to Mary Zawoysky for organic carbon measurements and editorial help and to Rosemary Bassilakis at Advanced Fuel Research for assistance in running the TG-FTIR analyses.

This research was supported by an Ocean Drilling Program Grant (No. 260641) and a Department of Energy Grant (No. DE-FG0286ER13466) to JW, and a National Science Foundation Grant (No. OCE-9116537) to JS and JW at the Woods Hole Oceanographic Institution. The solid-state NMR analyses were provided in part by Department of Energy University Research Instrumentation grant No. DE-FG05-89ER75506 to FM at the Western Research Institute. Woods Hole Oceanographic Institution Contribution No. 8295.

\section{REFERENCES}

Barker, C.E., 1983. Influence of time on metamorphism of sedimentary organic matter in liquid-dominated geothermal systems, western North America. Geology, 11:384-388.

_ 1991. Implications for organic maturation studies of evidence for a geologically rapid increase and stabilization of vitrinite reflectance at peak temperature: Cerro Prieto Geothermal System, Mexico. AAPG Bull., 75:1852-1863.

Barker, C.E., and Pawlewicz, M.J., 1986. The correlation of vitrinite reflectance with maximum paleotemperature in humic organic matter. In Bunte- barth, G., and Stegena, L. (Eds.), Paleogeothermics: New York (Springer Verlag), 79-93.

Bostick, N.H., 1971. Thermal alteration of clastic organic particles as an indicator of contact and burial metamorphism in sedimentary rocks. In Perkins, B.F. (Ed.), Geoscience and Man. Am. Assoc. Stratigr. Palynol., 3:83-92.

Davis, E.E., Mottl, M.J., Fisher, A.T., et al., 1992. Proc. ODP, Init. Repts., 139: College Station, TX (Ocean Drilling Program).

Dennis, L.W., Maciel, G.E., Hatcher, P.G., and Simoneit, B.R.T., $1982 .{ }^{13} \mathrm{C}$ nuclear magnetic resonance studies of kerogen from Cretaceous black shales thermally altered by basaltic intrusions and laboratory simulations. Geochim. Cosmochim. Acta, 46:901-907.

Durand, B., and Nicaise, G., 1980. Procedures for kerogen isolation. In Durand, B. (Ed.), Kerogen Insoluble Organic Matter From Sedimentary Rocks: Paris (Editions Technip), 35-53.

Hood, A., Gutjahr, C.C.M., and Heacock, R.L., 1975. Organic metamorphism and the generation of petroleum. AAPG Bull., 59:986-996.

Jones, R.N., and Edison, T.A., 1979. Microscopic observations of kerogen related to geochemical parameters with emphasis on thermal maturation. In Oltz, P.F. (Ed.), Low Temperature Metamorphism of Kerogen and Clay Minerals. Symp. in Geochem., Pacif. Sect., Soc. Econ. Paleontol. Mineral., 1-12.

Krom, M.D., and Berner, R.A., 1983. A rapid method for the determination of organic and carbonate carbon in geological samples. J. Sediment. Petrol., $53: 660-663$.

Miknis, F.P., Netzel, D.A., Smith, J.W., Mast, M.A., and Maciel, G.E., 1982. ${ }^{13} \mathrm{C}$ NMR measurements of the genetic potentials of oil shales. Geochim. Cosmochim. Acta, 46:977-984.

Peters, K.E., Simoneit, B.R.T., Brenner, S., and Kaplan, I.R., 1978. Vitrinite reflectance-temperature determinations for intruded Cretaceous black shale in the Eastern Atlantic. In Oltz, D.F. (Ed.), Low Temperature Metamorphism of Kerogen and Clay Minerals. Pac. Sect., Soc. Econ. Paleontol. Mineral., 53-58.

Snape, C.E., Axelson, D.E., Botto, R.E., Dulpuech, J.J., Tekely, P., Gerstein, B.C., Pruski, M., Maciel, G.E., and Wilson, M.A., 1989. Quantitative reliability of aromaticity and related measurements on coals by $13 \mathrm{C}$ n.m.r. A debate. Fuel, 68:547-580.

Sweeney, J.J., and Burnham, A.K., 1990. Evaluation of a simple model of vitrinite reflectance based on chemical kinetics. AAPG Bull., 74:15591570.

Tarafa, M.E., Whelan, J.K., and Mountain, G.S., 1987. Sediment slumps in the Middle and Lower Eocene of Deep Sea Drilling Project Holes 605 and 613: chemical detection by pyrolysis techniques. In Poag, C.W., Watts, A.B., et al., Init. Repts. DSDP, 95: Washington (U.S. Govt. Printing Office): $661-669$.

Walker, A.L., McCulloh, T.H., Petersen, N.F., and Stewart, R.J., 1983. Anomalously low reflectance of vitrinite in comparison with other petroleum source-rock maturation indices, from the Miocene Modelo Formation in the Los Angeles Basin, California. In Isaacs, C.M., and Garrison, R.E. (Eds)., Petroleum Generation and Occurrence in the Miocene Monterey Formation, California. Soc. Econ. Paleontol. Mineral., 185-190.

Whelan, J.K., Carangelo, R.M., and Solomon, P.R., 1990. TG-FTIR - a pyrolysis method for following maturation of oil and gas generation zones using $\mathrm{T}_{\max }$ of methane. Org. Geochem., 16:1187-1201.

Whelan, J.K., Oremland, R., Tarafa, M., Smith, R., Howarth, R., and Lee, C., 1986. Evidence for sulfate-reducing and methane producing microorganisms in sediments from Sites 618, 619, and 622. In Bouma, A.H., Coleman, J.M., Meyer, A.W., et al., Init. Repts. DSDP, 96: Washington (U.S. Govt. Printing Office), 767-775.

Whelan, J.K., Solomon, P.R., Deshpande, G.V., and Carangelo, R.M., 1988. Thermogravimetric Fourier transform infrared spectroscopy (TG-FTIR) of petroleum source rocks. Initial results. Energy Fuels, 2:65-73.

Wilson, M.A., Vassallo, A.M., Gizachew, D., and Lafargue, E., 1991. A high resolution solid state nuclear resonance study of some coaly source rocks from the Brent Group (North Sea). Org. Geochem., 17:107-111.

\footnotetext{
-Abbreviations for names of organizations and publications in ODP reference lists follow the style given in Chemical Abstracts Service Source Index (published by American Chemical Society).
}

Date of initial receipt: 26 February 1993

Date of acceptance: 2 July 1993

Ms 139SR-240 